\title{
Bibliometric Analysis of Literature Published on Antibacterial Dental Adhesive from 1996-2020
}

\author{
Abdul Samad Khan ${ }^{1, *(\mathbb{D})}$, Shafiq Ur Rehman ${ }^{2}{ }^{(D}$, Yara Khalid AlMaimouni ${ }^{1}{ }^{(}$, Shakil Ahmad ${ }^{3}(\mathbb{D}$, \\ Maria Khan ${ }^{4}$ and Murtaza Ashiq ${ }^{5}$ \\ 1 Department of Restorative Dental Sciences, College of Dentistry, Imam Abdulrahman Bin Faisal University, \\ Dammam 31441, Saudi Arabia; ykalmaimouni@iau.edu.sa \\ 2 Deanship of Library Affairs, Imam Abdulrahman Bin Faisal University, Dammam 31441, Saudi Arabia; \\ suRehman@iau.edu.sa \\ 3 Central Library, Prince Sultan University, Riyadh 11586, Saudi Arabia; shakil@psu.edu.sa \\ 4 Department of Oral Biology, University of Health Sciences, Lahore 54000, Pakistan; \\ mariakhan1685@gmail.com \\ 5 Islamabad Model College for Boys, H-9, Islamabad 44000, Pakistan; gmurtazaashiq00@gmail.com \\ * Correspondence: akhan@iau.edu.sa; Tel.: +966-594-781-075
}

Received: 7 November 2020; Accepted: 26 November 2020; Published: 29 November 2020

\begin{abstract}
This study aimed to investigate the current state of research on antibacterial dental adhesives. The interest in this field can be drawn from an increasing number of scholarly works in this area. However, there is still a lack of quantitative measurement of this topic. The main aim of this study was to consolidate the research published on the antibacterial adhesive from 1996 to 2020 in Web of Science indexed journals. The bibliometric method, a quantitative study of investigating publishing trends and patterns, was used for this study. The result has shown that a gradual increase in research was found, whereby a substantial increase was observed from 2013. A total of 248 documents were published in 84 journals with total citations of 5107. The highly cited articles were published mainly in Q1 category journals. Most of the published articles were from the USA, China, and other developed countries; however, some developing countries contributed as well. The authorship pattern showed an interdisciplinary and collaborative approach among researchers. The thematic evaluation of keywords along with a three-factor analysis showed that 'antibacterial adhesives' and 'quaternary ammonium' have been used commonly. This bibliometric analysis can provide direction not only to researchers but also to funding organizations and policymakers.
\end{abstract}

Keywords: dental adhesives; antibacterial adhesives; bonding agents; bibliometric analysis; mapping review; Web of Science; healthcare

\section{Introduction}

Adhesive dentistry is an integral part of the contemporary aesthetic restoration, and it is constantly evolving to promote conservative dentistry [1]. The polymer-based adhesive restorations have been extensively used along with five hundred million composite restorations per year [2]. The history of dental adhesives started in 1949 with the concept of adhesion to dentin through physical and chemical bonds. In 1954, the first experiment on adhesion to enamel was successfully done with acid etching [3,4]. With advancing technologies, new generations were introduced from non-etch to total-etch (fourth and fifth generation) to self-etch universal adhesives (eighth generation) systems. One promising advancement includes the addition of novel biomaterials that can effectively regulate mineral deposition in dentin and promote remineralization [5]. Modifying adhesives to improve the chemical stability of resin-based restoration have shown resistance against esterase and water 
degradation. For instance, formulating a bioadhesive modified with catechol groups such as synthetic mussel biomimetic polymers can significantly improve shear bond strength and water-resistance properties [6]. Moreover, adding antimicrobials and enzymatic inhibitors can reduce biofilm formation and penetration within adhesive interfaces [7].

The adhesive interface should remain stable over time to provide clinical durability for dental restorations with proper marginal seal. However, all adhesive systems are susceptible to degradation [8]. Interaction with active bacterial enzymes, dental biofilm, and various enzymes can lead to chemical breakdown [1]. Subsequently, degradation of interfaces may lead to adhesive failure causing microleakage, separation, and micro-movement between materials [9]. Microleakage at the dentin-adhesive interface can allow the growth and accumulation of bacterial biofilm, which causes dental caries $[10,11]$. The addition of antibacterial agents in dental restoration systems can interfere with the growth and reproduction of residual bacteria and prevent the invasion of new bacteria [12]. Thus, reducing secondary caries occurrence and improving the longevity of dental restorations [13]. It is estimated that a total of $\$ 298$ billion is spent globally every year for the replacement of failed restorations; this represents an average of $4.6 \%$ of the total global healthcare related expenditures [14].

Antibacterial agents can be leachable compounds, polymerizable monomers, and filler particles [15]. Several studies have been conducted to evaluate the effect of adding nanoparticles such as silver, calcium phosphate, zinc oxide, and titanium dioxide in various restorative materials, including glass ionomer cements, resin-based materials, and dental adhesives [16-18]. The quaternary ammonium compounds (QAC) have been used in composite restorations and impact the polymeric structure, degree of conversion, solvent sorption, shrinkage, and alter the biocompatibility behavior [19]. It is reported that the antibacterial activity of QAC containing restorative materials, were adversely altered due to electrostatic interaction between saliva and QAC [20]. The addition of antibacterial agents in adhesive systems helps to improve the stability of dentin-resin interface that is essential for the durability of restorations [21-23]. Antibacterial components' addition can positively affect interfacial bonding [24], decrease bacterial viability [25], inhibit matrix metalloproteinase, and most importantly, it reduces the effect of causative factors initiating chemical degradation of dental adhesives [22,26]. The antibacterial dental adhesive is the primary restorative material with the ability to restrict or inhibit secondary caries. In the last few years, significant interest related to antibacterial dental adhesives has been noticed, and few literature review articles have been published on the use of antibacterial monomers and nanoparticles in dental adhesives [19,27,28]. However, it is essential that the studies related to this topic should be analyzed so that their impact on applied research in the field of adhesive dentistry can be evaluated. One of the methods to evaluate the impact in applied science can be through bibliometric analysis. Bibliometric analysis has been performed in various sub-specialties of dentistry including periodontology [29], oral and maxillofacial surgery [30], implantology [31], orthodontics [32], prosthodontics [33], pediatric dentistry [34], and endodontics [35]. However, the authors could not find any bibliographic study where studies on antibacterial dental adhesive were assessed quantitatively. Therefore, in this study, various aspects were considered to assess the publications and citation trends in antibacterial dental adhesive from 1996-2020. The other research questions of this study were:

1. Which are the leading countries and institutions in antibacterial dental adhesive literature?

2. Which are the most influential journals in antibacterial dental adhesive literature?

3. Which are the most trending and cited publications of antibacterial dental adhesive literature?

4. What are the authorship and collaboration research patterns of antibacterial dental adhesive researchers?

5. What are emerging research themes/keywords in antibacterial dental adhesive literature?

\section{Methodology}

The bibliometric study investigates the publishing trends of antibacterial dental adhesive literature indexed in Web of Science (WOS) core collection database. It is recognized that WOS is the most 
authentic and reliable indexing and abstracting database globally, whereas bibliometric analysis is a statistical method to analyze the publishing trends, patterns, and scope of the published scholarly work. A comprehensive four-phased search and selection strategy was framed, as shown in Figure 1, to include publications to conduct bibliometric analysis. The following query was designed, adding all the relevant keywords, to run into Web of Science core collection to retrieve the results. Boolean operators were used to combine the keywords to retrieve the maximum and relevant results. (TS = (dental adhesive AND antibacterial OR dental bonding agent AND antibacterial OR dental adhesive AND antibacterial activity OR dental adhesive AND biofilm OR antibacterial dental adhesives OR dental adhesive AND bacteria OR dental adhesive AND quaternary ammonium derivative OR dental adhesive AND antibacterial monomers OR dental adhesive AND anti-bacterial activity OR dental adhesive AND antibacterial effect OR dentin bonding AND antibacterial effect OR dental adhesive AND silver OR dental adhesives AND antibacterial agent OR dental adhesive AND antibacterial particles)).

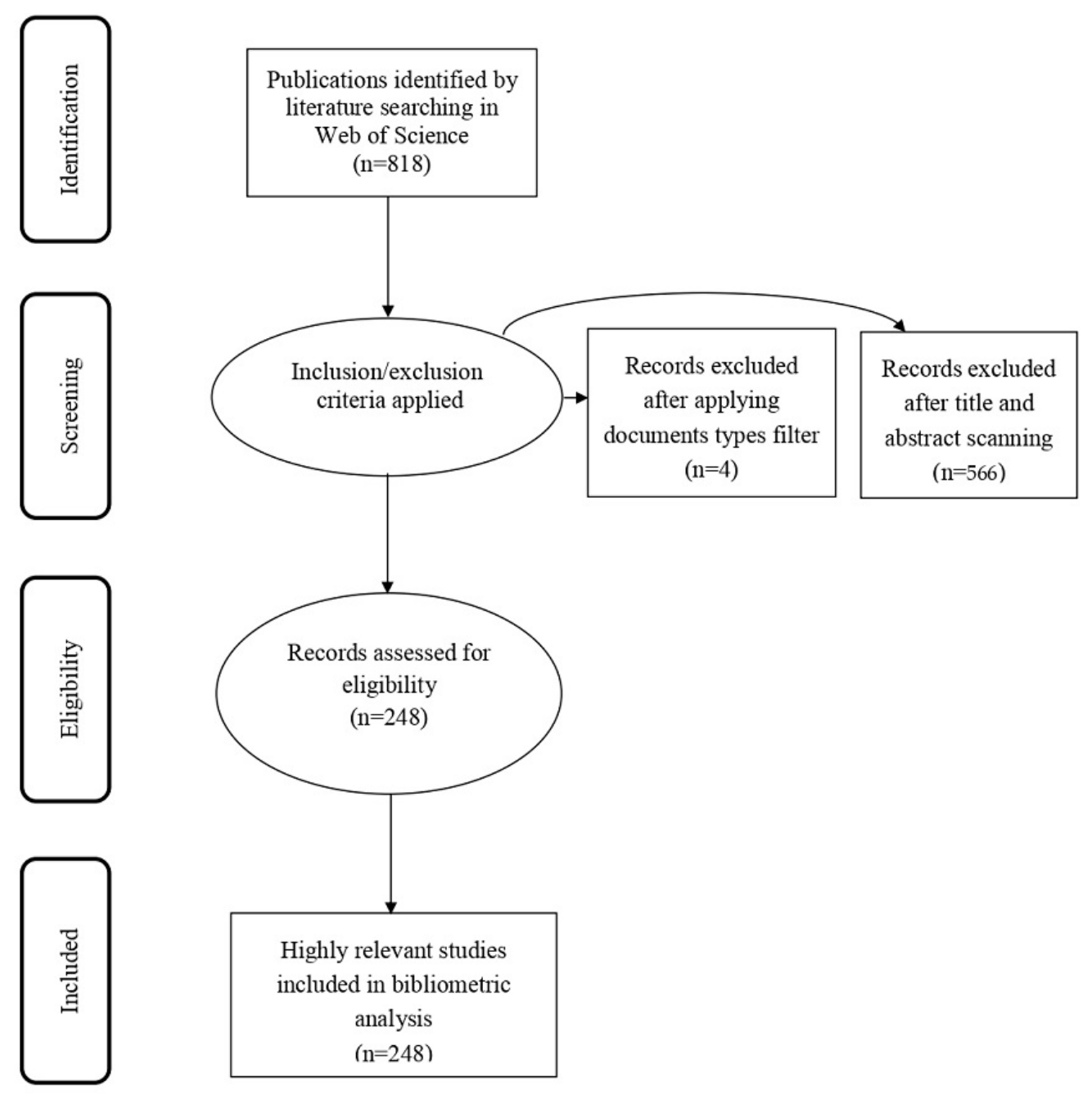

Figure 1. Four-phase flow diagram of data extraction and filtration process of dental adhesive publications.

\subsection{Search Strategy}

For inclusion and recall of maximum relevant records, a WOS core collection field (it has over 21,000 peer-reviewed journals published worldwide) has been selected, and further, the "Advanced Search" facility of WOS core collection database was chosen. There was no filter applied (language and timespan) while retrieving the results/records. A total of 818 records appeared, which were downloaded on 7 July 2020. 


\subsection{Inclusion and Exclusion Criteria}

For the precision purpose, inclusion and exclusion criteria were applied to refine the results further. Inclusion Criteria: The authors did not find any irrelevant records to exclude at the eligibility stage. Two hundred and forty-eight (248) records were assessed to process at the eligibility stage, and these records obtained a total of 5107 citations. The included document types were articles (234 articles obtained 5033 citations), review articles ( 7 articles obtained 46 citations), proceeding papers (6 documents obtained 28 citations), and early access (one document with no citation).

Exclusion Criteria: For this purpose, the filter of "document types" was applied and only "articles, review articles, proceeding papers, and early access" were retrieved. This purification process helps to remove four documents. To ensure the accuracy and relevancy of the data, each record was thoroughly read (title and abstract), and 570 irrelevant and duplicate records were excluded from the data.

\subsection{Data Analysis}

Finally, 248 highly relevant records [10,24,25,36-278] on antibacterial dental adhesive were selected for data analysis and visualization using various bibliometric applications and software, including MS Excel, VOSViewer, Biblioshiny (RStudio), CiteSpace, and BibExcel.

\subsection{Terms Used in Data Analysis}

Some terms/abbreviations are used for data analysis in various columns of tables as TP stands for total publications, TC for total citations, IF for impact factor, $Q$ for journal quartile, and FY for the first year of publication on this specific topic/area. The citation impact describes the average citation received by a specific publication. The citation impact $(\mathrm{CI})$ in this study was calculated by dividing the total number of citations by the total number of publications. This illustrates the average number of citations that a specific publication has received [279]. In addition, there are some terminologies defined by Web of Science database that were used as U1, U2, and Z9. U1 refers to the usage count of the last 180 days. Usage count is briefed by Web of Science as "the count of the number of times the full text of a record has been accessed, or a record has been saved in the last 180 days. This count can move up or down as the end date of the fixed period advances" [280]. Since the data was retrieved on 19 July 2020, so the last 180 days begin from this date. Similarly, U2 is the usage count since 2013, and Z9 is the total times cited count from (Web of Science Core Collection, Arabic Citation Index, BIOSIS Citation Index, Chinese Science Citation Database, Data Citation Index, Russian Science Citation Index, SciELO Citation Index). Moreover, the usage count is updated on a daily basis [280].

\section{Results}

\subsection{Analysis of the Overall Growth Trend}

Figure 2 presents the total number of publications and citations on dental adhesive literature. It shows that this area has grown tremendously in the last couple of years of the 20th century. The first few years have observed little progress as the first publication appeared in 1996. Four publications in the first five years (1996-2000) have obtained 289 citations; however, the growth has been increasing each year gradually. The notable publications have been indexed from 2013 onwards, whereas the citations have been gradually increasing annually. The boom of the publications and citations was $2018(\mathrm{TP}=36)$ and $2013(\mathrm{TC}=866)$, respectively.

\subsection{Most Productive Countries and Organization on Antibacterial Dental Adhesive Research}

Table 1 presents the top 10 most productive countries on dental antibacterial adhesive literature globally. There are five countries having publications in double-digits, and three countries produced over 50 publications individually. The United States of America emerged as a top country with the highest publications (99), citations (2480), and total link strength score (1202), followed by China with 
91 publications and 2473 citations and Brazil with 59 publications and 861 citations. It is interesting to highlight that Spain is at the bottom of the table with only six publications, and Japan is ranked fourth; however, their publications gain the highest citation impact, 46.83 and 41.68, respectively.

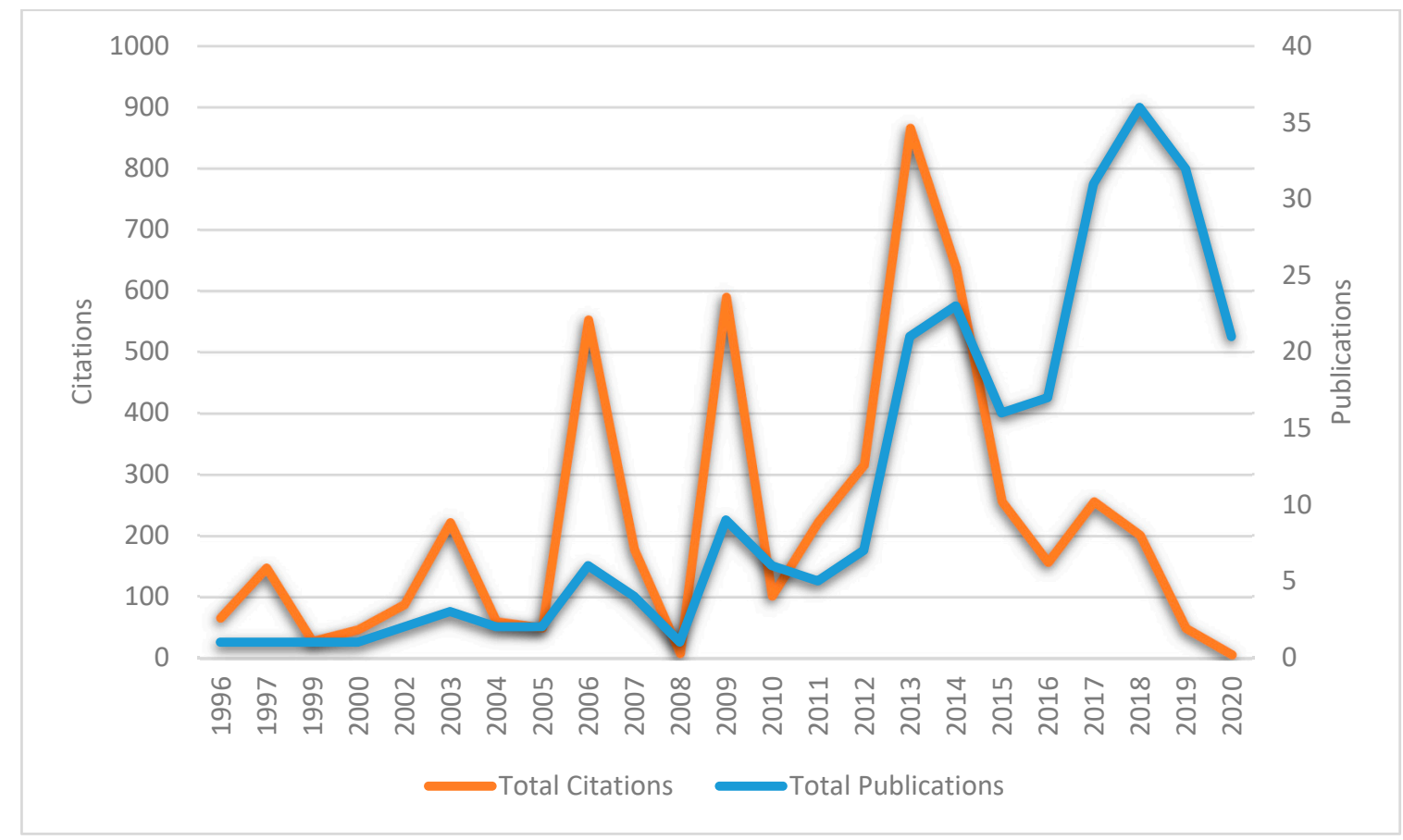

Figure 2. Publishing and citation trends in antibacterial dental adhesive research.

Table 1. Most influential countries and organizations in terms of total publications (TP), total citations (TC), and citation impact (CI)

\begin{tabular}{|c|c|c|c|c|c|c|c|c|c|c|}
\hline Rank & Country & TP & TC & CI & Rank & Organizations & Country & TP & TC & CI \\
\hline 1 & USA & 99 & 2480 & 25.05 & 1 & $\begin{array}{c}\text { The University of } \\
\text { Maryland }\end{array}$ & USA & 53 & 1713 & 32.32 \\
\hline 2 & China & 91 & 2473 & 27.18 & 2 & Sichuan University & China & 32 & 1128 & 35.25 \\
\hline 3 & Brazil & 59 & 861 & 14.59 & 3 & $\begin{array}{l}\text { Capital Medical } \\
\text { University }\end{array}$ & China & 25 & 877 & 35.08 \\
\hline 4 & Japan & 22 & 917 & 41.68 & 4 & $\begin{array}{c}\text { Fourth Military } \\
\text { Medical University }\end{array}$ & China & 24 & 984 & 41.00 \\
\hline 5 & Turkey & 13 & 195 & 15.00 & 5 & $\begin{array}{l}\text { University of Maryland, } \\
\text { Baltimore County }\end{array}$ & USA & 21 & 932 & 44.38 \\
\hline 6 & Canada & 8 & 44 & 5.50 & 6 & Osaka University & Japan & 16 & 810 & 50.63 \\
\hline 7 & Italy & 8 & 137 & 17.13 & 7 & $\begin{array}{c}\text { Universidade Estadual } \\
\text { De Campinas }\end{array}$ & Brazil & 12 & 93 & 7.75 \\
\hline 8 & Germany & 6 & 131 & 21.83 & 8 & $\begin{array}{l}\text { Federal University of } \\
\text { Rio Grande do Sul }\end{array}$ & Brazil & 11 & 71 & 6.45 \\
\hline 9 & $\begin{array}{l}\text { South } \\
\text { Korea }\end{array}$ & 6 & 199 & 33.17 & 9 & $\begin{array}{l}\text { Universidade Estadual } \\
\text { de Ponta Grossa }\end{array}$ & Brazil & 9 & 72 & 8.00 \\
\hline 10 & Spain & 6 & 281 & 46.83 & 10 & $\begin{array}{c}\text { National Institute of } \\
\text { Standards and } \\
\text { Technology }\end{array}$ & USA & 7 & 164 & 23.43 \\
\hline
\end{tabular}

Among the top 10 organizations, the University of Maryland produced 53 publications and 1713 citations, followed by Sichuan University with 32 publications and 1128 citations. It is worth mentioning that Osaka University is at the sixth rank (16 publications, 810 citations) but has the highest citation impact $(\mathrm{CI}=50.63)$. 


\subsection{Highly Influential Journals}

Table 2 records the highly productive top ten journals on dental antibacterial adhesive literature. Most of the sources have produced 10 and fewer than 10 publications. The source Dental Materials is on the top of the list with a remarkable number of publications (40), citations (1468), citation impact (36), fall in Quartile 1 and has impact factor 4.5 followed by Journal of Dentistry at 2nd rank with 29 publications, 747 citations, 25.76 citation impact, Quartile 1 and with impact factor 3.24. The source with the highest impact factor Acta Biomaterialia (7.24) has produced 10 publications and obtained 312 citations. All included sources are impact factor from Quartile 1-3 and half of them belong to The Netherlands, four from the United States of America, and one from Japan.

Table 2. Highly influential journals in relation to published articles on antibacterial dental adhesives

\begin{tabular}{|c|c|c|c|c|c|c|c|}
\hline Source & TP & TC & CI & Country & Publisher & IF & $\mathbf{Q}$ \\
\hline Dental Materials & 40 & 1468 & 36.70 & The Netherlands & Elsevier & 4.5 & 1 \\
\hline Journal of Dentistry & 29 & 747 & 25.76 & The Netherlands & Elsevier & 3.24 & 1 \\
\hline Acta Biomaterialia & 10 & 312 & 31.20 & The Netherlands & Elsevier & 7.24 & 1 \\
\hline Journal of Dental Research & 10 & 594 & 59.40 & USA & Sage & 4.91 & 1 \\
\hline Journal of Adhesive Dentistry & 9 & 119 & 13.22 & USA & $\begin{array}{l}\text { Quintessence } \\
\text { Publishing }\end{array}$ & 2.38 & 2 \\
\hline $\begin{array}{l}\text { Journal of Biomedical } \\
\text { Materials Research Part } \\
\text { B-Applied Biomaterials }\end{array}$ & 9 & 246 & 27.33 & USA & Wiley & 2.83 & 3 \\
\hline $\begin{array}{c}\text { International Journal of } \\
\text { Adhesion and Adhesives } \\
\text { Journal of The }\end{array}$ & 8 & 21 & 2.63 & The Netherlands & Elsevier & 2.67 & 2 \\
\hline $\begin{array}{l}\text { Mechanical Behavior of } \\
\text { Biomedical Materials }\end{array}$ & 6 & 13 & 2.17 & The Netherlands & Elsevier & 3.37 & 2 \\
\hline Operative Dentistry & 6 & 176 & 29.33 & USA & $\begin{array}{l}\text { Operative Dentistry } \\
\text { Japanese Society for }\end{array}$ & 2.21 & 2 \\
\hline Dental Materials Journal & 5 & 14 & 2.80 & Japan & $\begin{array}{l}\text { Dental Materials } \\
\text { and Devices }\end{array}$ & 1.36 & 3 \\
\hline
\end{tabular}

\subsection{Authorship Pattern}

Figure 3 describes the authorship pattern on dental antibacterial adhesive literature. The authorship pattern ranges from a minimum of one author to a maximum of 15 authors. There are only two publications as single-author, four publications as two-authors, and 14 publications as three-authors. It shows the trend of collaborative research pattern in this area has the highest numbers of publications (46) that were produced by six-authors, 42 produced by five-authors, 36 produced by four-authors, and 30 publications by seven and more-authors. There are 14 publications with more than 10 authors. Overall, the authorship patterns inform that collaborative studies (more than three-authors) are being implied in dental antibacterial adhesive literature worldwide.

\subsection{Authors' Keyword Analyses on Antibacterial Dental Adhesive}

Figure 4 presents the authors' keyword analysis on dental antibacterial adhesive literature. Three minimum number of occurrences of a keyword were selected; hence, out of total 587 authors' keywords, 83 meet this criterion consisting of seven clusters. Each color represents a separate cluster and clusters are arranged on the basis of link strength and occurrence. Hence, the size of the bubble indicates the nature of the relationship with link strength and occurrence. The five keywords with the highest total link strength are antibacterial (link strength: 59), dental adhesive (55), antibacterial activity (52), caries inhibition (50), and streptococcus mutans (50). 


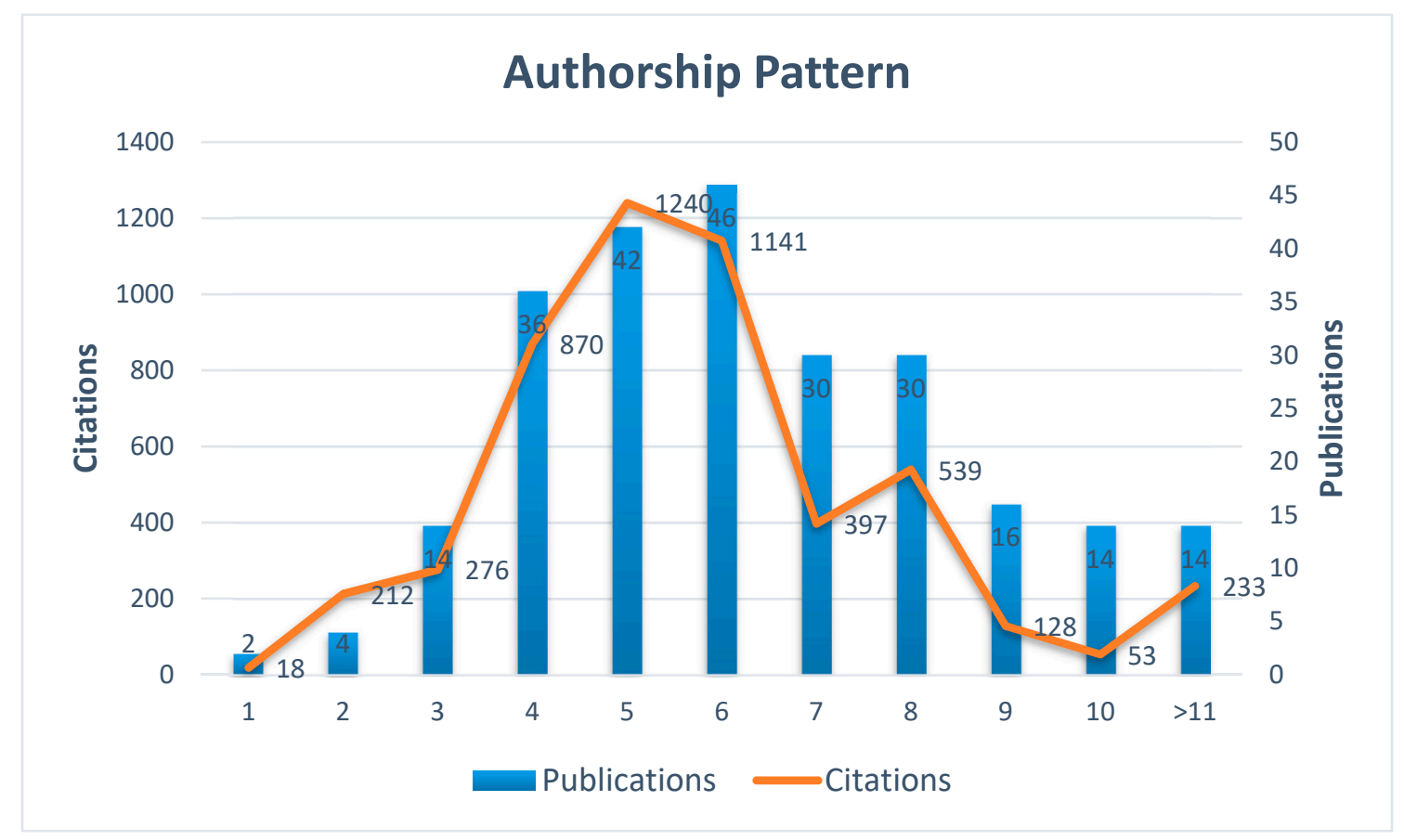

Figure 3. Authorship pattern of antibacterial dental adhesive literature.

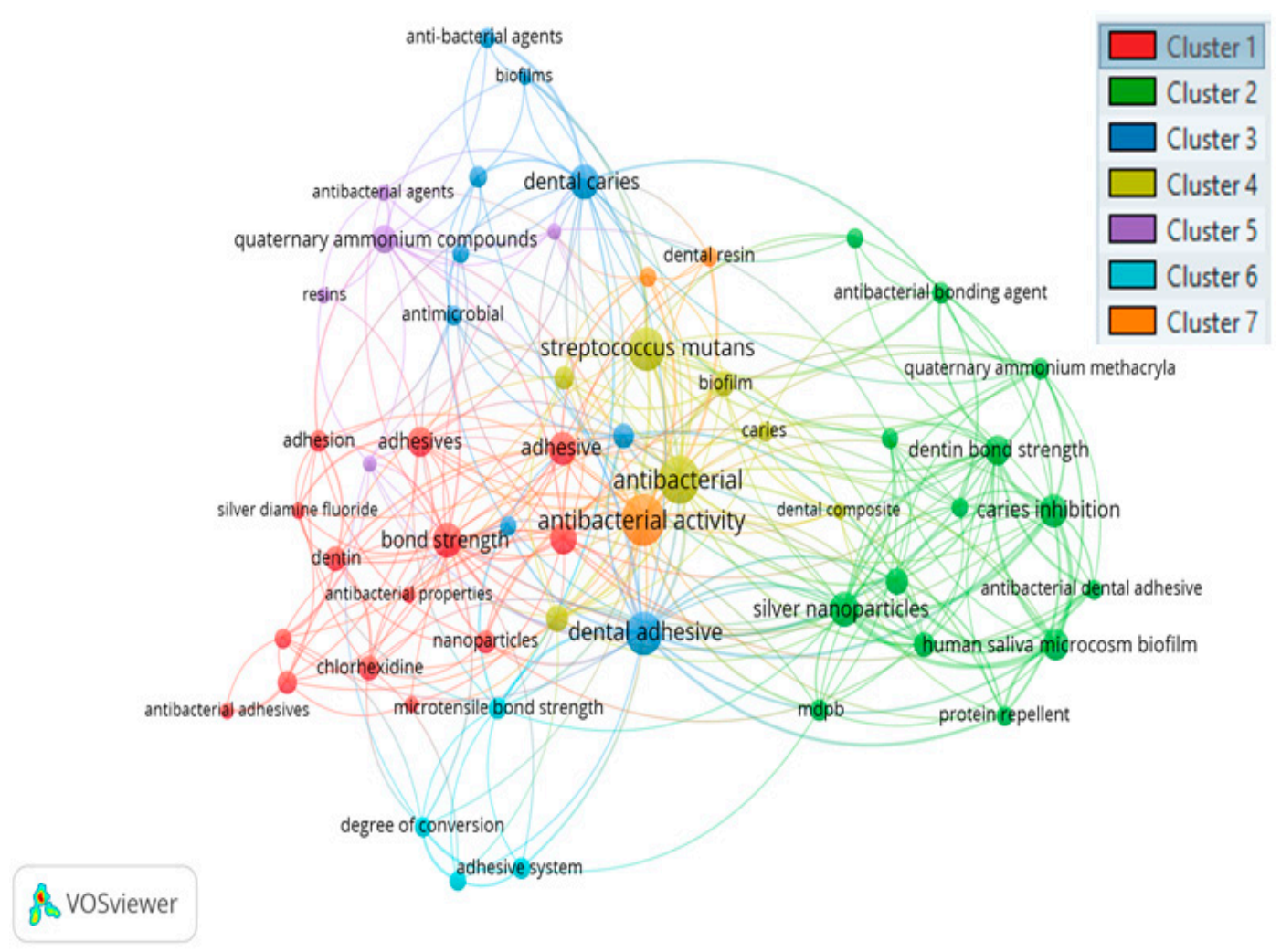

Figure 4. Co-occurrence network of author keywords (minimum number of occurrences: three). A co-occurrence network is a relationship of two or more keywords occurring together. In this figure, there are seven clusters (indicating various colors) having relationship with each other. Cluster one is the strongest network relationship, followed by 2-7 clusters, respectively. The top keyword 'antibacterial' having the strongest relationship and occurred maximum in antibacterial dental adhesive literature. 


\subsection{Thematic Evolution Map of Author Keywords}

The thematic evolution of keywords during the last 25 years shows a clear shift in antibacterial dental adhesive research streams. Caries inhibition, adhesion, silver nanoparticles, related keywords disappeared after 2013 (Figure 5). The results show that antibacterial dentistry, chlorhexidine, dental caries, antibacterial monomers, and antimicrobial peptides were hot topics from 2014 to 2020. In addition, antibacterial activities, adhesive, antibacterial, quaternary ammonium were important keywords throughout the 25 years (1996-2020).

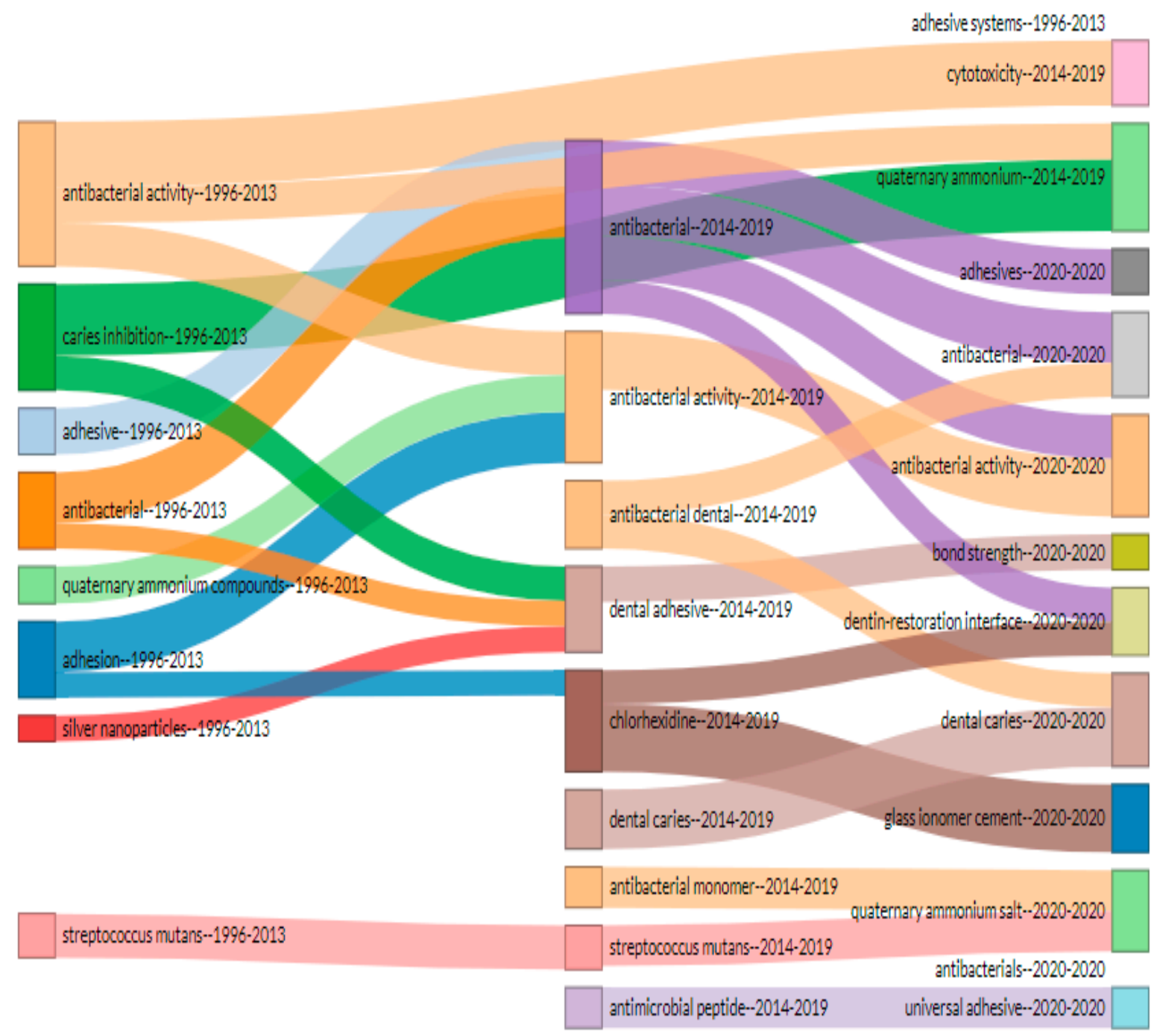

Figure 5. Thematic evolution map of keywords from 1996 to 2020 with respect to antibacterial dental adhesives. This map highlights the usage and emergence of various keywords related to antibacterial dental adhesive literature. It is evident that antibacterial activities, adhesive, antibacterial, quaternary ammonium were important keywords throughout the 25 years (1996-2020). Few keywords—such as chlorhexidine, antimicrobial peptides, antimicrobial monomers, etc.-emerged from 2014.

\subsection{Highly Cited Articles on Antibacterial Dental Adhesive}

Table 3 presents the bibliographic information of the top ten highly cited articles on dental antibacterial adhesive. The top 10 highly cited articles' citations and years ranged a maximum of 300 to 95 citations and 1997 to 2013, respectively. There are two articles that obtained over 150 citations. The article titled "Antibacterial Activity of Dental Composites Containing Quaternary Ammonium Polyethyleneimine Nanoparticles Against Streptococcus mutans" by Beyth N, published in Biomaterials 
in the year 2006, is on the top of the list with the highest citations (300), average citation (21.43), followed by an article written by Imazato S. that obtained 181 citations. Interestingly, more than half of the highly cited articles were published in Dental Material Journal, and this journal is also on the top of the list of most influential sources (Table 2).

Table 3. Top 10 highly cited articles on antibacterial dental adhesive

\begin{tabular}{|c|c|c|c|c|c|}
\hline Title & Author & Source & TC & $\mathrm{C} / \mathrm{Y}$ & Year \\
\hline $\begin{array}{l}\text { Antibacterial Activity of Dental Composites } \\
\text { Containing Quaternary Ammonium } \\
\text { Polyethylenimine Nanoparticles Against } \\
\text { Streptococcus Mutans }\end{array}$ & Beyth et al. [55] & Biomaterials & 300 & 21.43 & 2006 \\
\hline $\begin{array}{l}\text { Antibacterial Activity and Bonding } \\
\text { Characteristics of An Adhesive Resin } \\
\text { Containing Antibacterial Monomer MDPB }\end{array}$ & Imazato et al. [137] & Dental Materials & 181 & 10.65 & 2003 \\
\hline $\begin{array}{l}\text { Incorporation of Antibacterial Monomer } \\
\text { MDPB into Dentin Primer }\end{array}$ & Imazato et al. [138] & $\begin{array}{l}\text { Journal of Dental } \\
\quad \text { Research }\end{array}$ & 148 & 11.38 & 1997 \\
\hline $\begin{array}{c}\text { Experimental Antimicrobial Orthodontic } \\
\text { Adhesives Using Nanofillers And } \\
\text { Silver Nanoparticles }\end{array}$ & Ahn et al. [36] & Dental Materials & 146 & 13.27 & 2009 \\
\hline $\begin{array}{l}\text { In Vitro Antibacterial Effects of The Dentin } \\
\text { Primer of Clearfil Protect Bond }\end{array}$ & Imazato et al. [139] & Dental Materials & 138 & 9.86 & 2006 \\
\hline $\begin{array}{l}\text { Effects of a Dental Adhesive Incorporating } \\
\text { Antibacterial Monomer on The Growth, } \\
\text { Adherence and Membrane Integrity of } \\
\text { Streptococcus Mutans }\end{array}$ & Li et al. [160] & $\begin{array}{l}\text { Journal of } \\
\text { Dentistry }\end{array}$ & 133 & 12.09 & 2009 \\
\hline $\begin{array}{l}\text { Anti-Biofilm Dentin Primer with } \\
\text { Quaternary Ammonium and } \\
\text { Silver Nanoparticles }\end{array}$ & Cheng et al. [72] & $\begin{array}{l}\text { Journal of Dental } \\
\text { Research }\end{array}$ & 116 & 14.50 & 2012 \\
\hline $\begin{array}{l}\text { An In Vivo Evaluation of Bonding Ability } \\
\text { of Comprehensive Antibacterial Adhesive } \\
\text { System Incorporating MDPB }\end{array}$ & Imazato et al. [141] & Dental Materials & 106 & 8.15 & 2007 \\
\hline $\begin{array}{l}\text { Effect of Quaternary Ammonium and } \\
\text { Silver Nanoparticle-Containing Adhesives } \\
\text { on Dentin Bond Strength and Dental } \\
\text { Plaque Microcosm Biofilms }\end{array}$ & Zhang et al. [269] & Dental Materials & 98 & 12.25 & 2012 \\
\hline $\begin{array}{c}\text { Novel Dental Adhesives Containing } \\
\text { Nanoparticles of Silver and Amorphous } \\
\text { Calcium Phosphate }\end{array}$ & Melo et al. [191] & Dental Materials & 95 & 101 & 2013 \\
\hline
\end{tabular}

\subsection{Three Factor (Sources, Countries, and Keywords) Relationships}

Figure 6 presents the three-factor analysis on the relationship among sources (left), countries (middle), and keywords (right) to better understand which countries prefer to publish with which keywords and in what sources. The relationship indicates that three top countries (USA, China, Brazil) have a strong relationship with six sources (Dental Material, Journal of Dentistry, Acta Biomaterialia, Journal of Dental Research, Journal of Biomedical Material Research, International Journal of Adhesion and Adhesive) and prefer to publish with eight keywords (antibacterial, antibacterial activity, dental adhesive, streptococcus mutans, adhesive, quaternary ammonium) respectively.

\subsection{Collaboration World Map of Dental Antibacterial Adhesive Literature}

Figure 7 describes the country collaboration map of dental antibacterial adhesive literature. There are a total of 56 collaboration entries recorded worldwide. The United States of America, China, and Brazil were the major collaborators with other countries worldwide. The Table in Figure 6 indicated the top ten collaborations show that major two collaborations have been between China and the USA (56) and the USA and Brazil (18). The rest of the 54 collaboration entries are in a single digit. Most of the collaborations' occurrence is one and two collaborations between various countries. There are 35 single collaborations (one collaboration) and 11 bi-collaborations (two collaborations). The remaining top 10 collaborations are highlighted in Figure 7. 


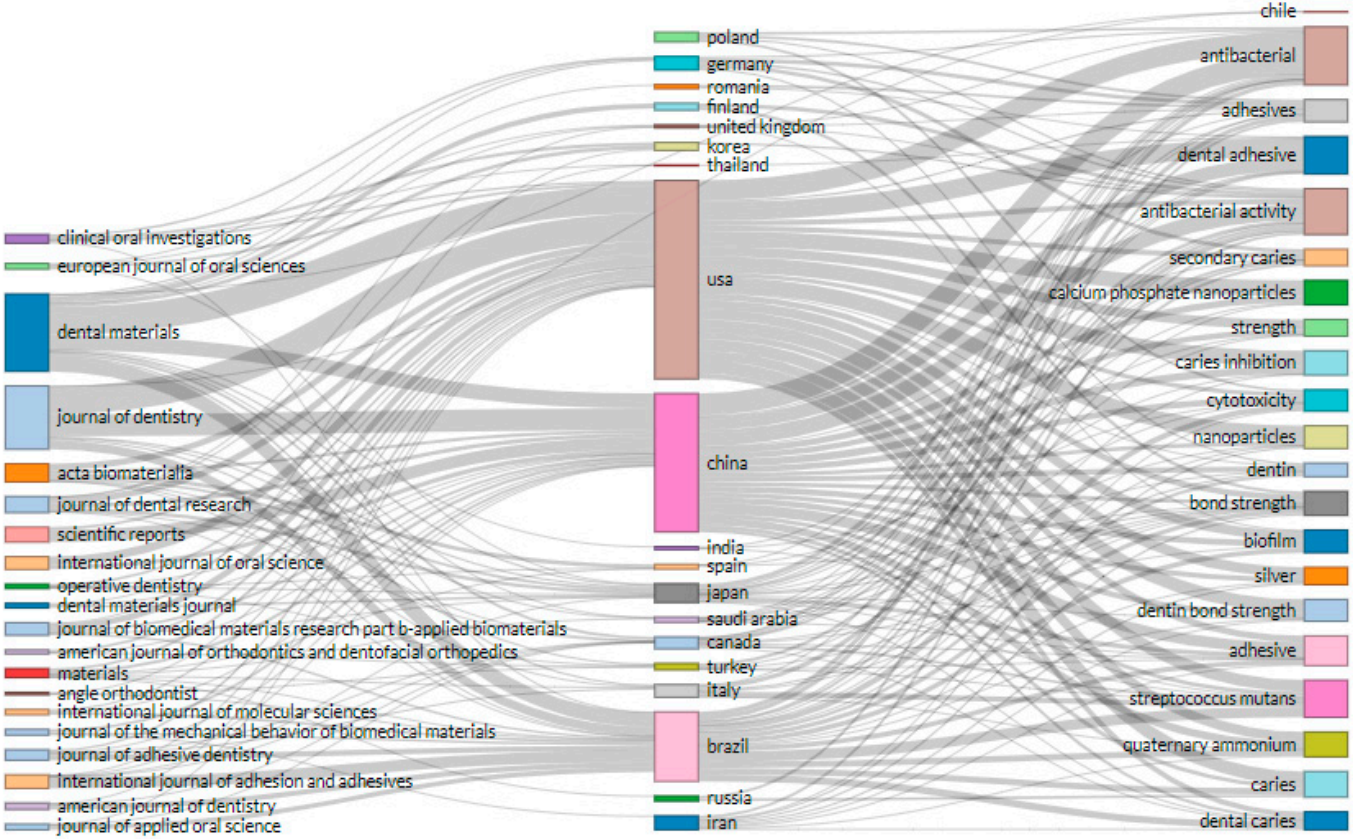

Figure 6. Three-factor plots of the relationship among keywords (left), countries (middle), and sources (right) on antibacterial dental adhesive literature. This figure shows that the researchers from top contributing countries (USA, China, and Brazil) prefer to publish their work in 'dental material' and 'journal of dentistry' with keywords like 'antibacterial', 'antibacterial activity', 'dental adhesive'. Most probably, in bibliometric studies, the top indicators include influential countries, sources, keywords, and authors. This figure shows that researchers from various countries prefer to publish their work in specific sources and with preferable keywords. The largest block shows a greater connection and relationship.

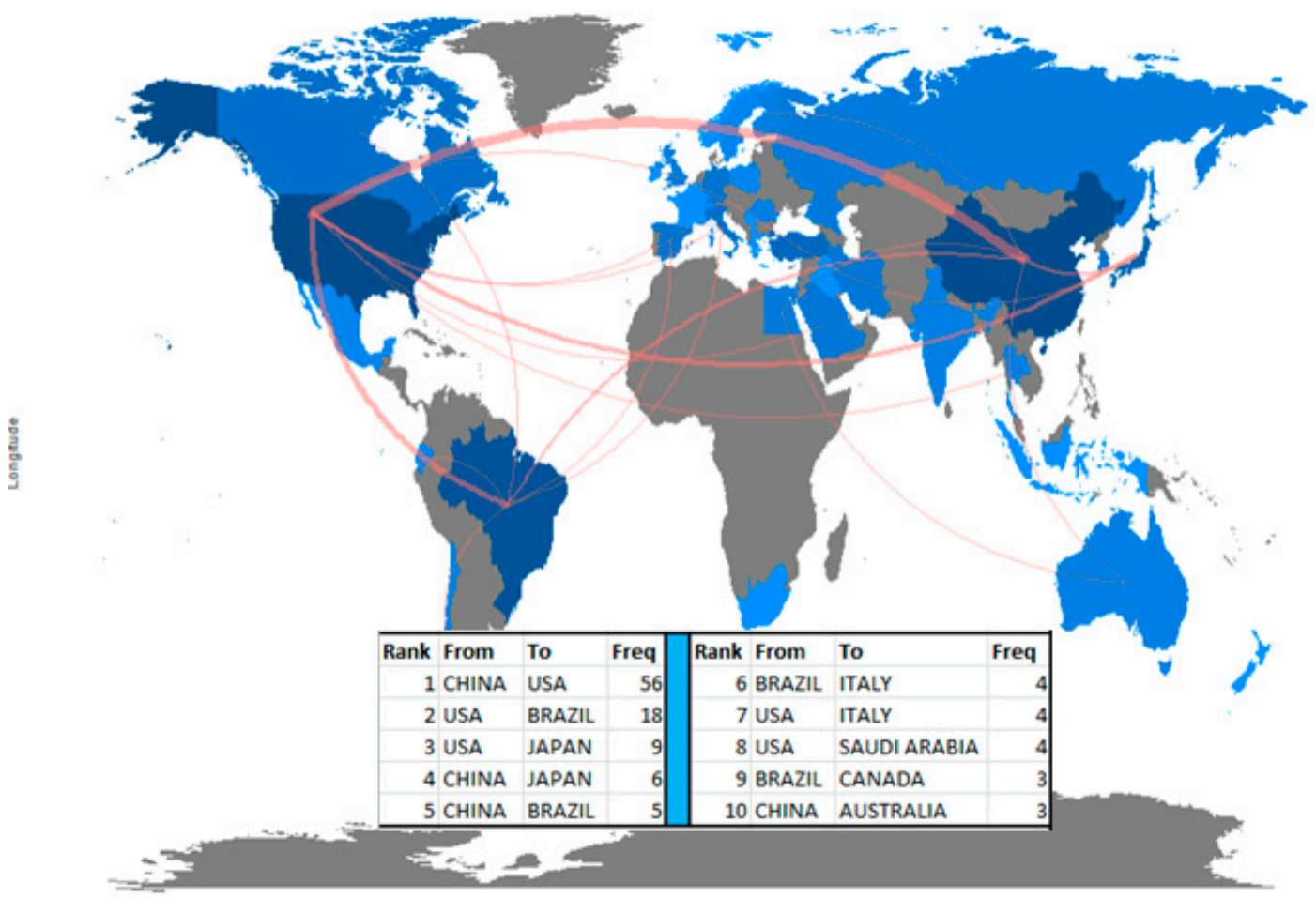

Figure 7. Country collaboration map on dental adhesive literature. 


\subsection{Citation Bursts of Dental Adhesive Literature}

Figure 8 describes the top 15 references of dental adhesive literature with the strongest citation bursts. These citation bursts expanded between the years 1996-2020. Most of the references ranged between the digits 3.00 to 5.00 as the strongest citation bursts. Albeit, the two citations on the top have the most expanded duration (1996-2012); however, the strength of their citation bursts is low (4.80 and 4.32), respectively. The reference of work written by Imazato S. in 1997 had the highest citation burst (8.44) and expanded between the years 2000-2012, whereas the reference with the least strength of citation bursts (3.49) was also written by Imazato S. in 1998.

\section{Top 15 References with the Strongest Citation Bursts}

\begin{tabular}{|c|c|c|c|c|}
\hline References & Year & trength Begin & End & $1996-2020$ \\
\hline BERGENHOLTZ G, 1982, J ORAL PATHOL MED, V11, P439, DOI & 1982 & 4.80651996 & 2012 & \\
\hline Emilson C G, 1993, Quintessence Int, V24, P511 & 1993 & 4.3241996 & 2012 & \\
\hline PRATI C, 1993, DENT MATER, V9, P338, DOI & 1993 & 5.8711997 & 2012 & \\
\hline Imazato S, 1997, J DENT RES, V76, P768, DOI & 1997 & 8.44272000 & 2012 & \\
\hline Meiers JC, 1996, OPER DENT, V21, P257 & 1996 & 3.62962000 & 2006 & \\
\hline Imazato S, 1999, BIOMATERIALS, V20, P899, DOI & 1999 & 5.38322003 & 2010 & \\
\hline Imazato S, 1998, J DENT, V26, P267, DOI & 1998 & 5.09222003 & 2009 & \\
\hline Atac AS, 2001, J ENDODONT, V27, P730 & 2001 & 4.15042003 & 2012 & \\
\hline Imazato S, 1998, AM J DENT, V11, P106 & 1998 & 4.15042003 & 2012 & \\
\hline Imazato S, 1998, J BIOMED MATER RES, V39, P511, DOI & 1998 & 3.49132003 & 2009 & \\
\hline Imazato S, 2001, J ORAL REHABIL, V28, P314, DOI & 2001 & 4.43282005 & 2009 & \\
\hline Imazato S, 2007, DENT MATER, V23, P170, DOI & 2007 & 4.0132009 & 2014 & \\
\hline Namba N, 2009, DENT MATER, V25, P424, DOI & 2009 & 3.52552012 & 2017 & \\
\hline Liu Y, 2011, J DENT RES, V90, P953, DOI & 2011 & 5.392015 & 2020 & \\
\hline Li F, 2014, DENT MATER, V30, P433, DOI & 2014 & 4.54022015 & 2020 & \\
\hline
\end{tabular}

Figure 8. Citation bursts of dental adhesive articles (1996-2020).

\section{Discussion}

The bibliometric analyses have been widely used methods for studying the structures and mechanisms of science. In this study, the qualitative evaluation of scientific publications as the direct output of research was performed using various variables (research questions), which are discussed below.

\subsection{Yearly Trend of Publications and Citations}

The bibliographic search in this study showed that the first paper related to this topic, i.e., the antibacterial dental adhesive, was published in 1996; however, no specific antibacterial agent was incorporated in the dental adhesive. Therein, the authors claimed that antibacterial activity was due to the presence of glutaraldehyde in the formulation. In the first four years, only one paper was published each year on this topic, whereby MDPB as antibacterial monomer was introduced in the dental adhesive in 1997 by Imazato and group. This paper was published in Journal of Dental Research (Q1) and got 258 citations, and was rated as the fourth most-cited article. The authors claimed that the knowledge of the effect of incorporating different concentrations of MDPB in dentin primer would help the clinicians and scientists to improve the performance of dental adhesives.

\subsection{Highly Productive and Cited Countries and Organizations}

The United States has the largest number of publications and citations. The scientific contribution of the USA to dental research and development occurred due to many factors; these include the establishment of the National Institute of Dental Research in 1948, funding opportunities from both government and private sectors, and the formation of scientific journals [281]. China was found to 
have the second-largest number of publications. This rise in publications from both countries can be attributed to the high frequency of collaboration between academic institutions in China and the USA. In addition, the top five influential organizations were from the USA and China, where the University of Maryland, USA, has the largest number of publications followed by three Chinese institutions.

\subsection{Highly Cited Papers}

Later, in the early 2000s (2002, 2003, and 2006), papers based on MDPB antibacterial adhesives were published by the same group and received citations. The paper published in Dental Materials (Q1) in 2006 by this group got fourth-highest citations (257). In 2006, Beyth et al. [55] utilized quaternary ammonium polyethyleneimine nanoparticles $(1 \mathrm{wt} \%)$ as an antibacterial agent in adhesives. The work was published in Biomaterials (Q1) and is the most-cited article (300 citations). The material was synthesized by cross linking PEI with dibromopentane monomer. The in vitro antibacterial testing showed no inhibition zone in the agar test, however, in direct contact test and eluted components the antibacterial ability of experimental adhesive was strongly evident even after 1 month of aging.

The second most-cited article by Imazato et al. [137] was published in the year 2003 (181 citations). This article was published in Dental Materials (Q1) and examined the antibacterial efficiency of $2.5 \%$ 12-methacryloyloxydodecylpyridinium bromide (MDPB) monomer in resin-based adhesive. The results showed that the inhibition zone was significantly higher in the experimental adhesive by a mean level of $97 \%$. The study confirmed the antibacterial ability of the modified resin adhesive without adversely affecting the bond strength or degree of conversion.

The third most-cited article is by Imazato et al. [138] published in Journal of Dental Research (Q1) in the year 1997 (148 citations), which assessed the antibacterial efficacy of incorporating 1, 2, and 5\% of MDPB into dentin primer against S. mutans, Actinomyces viscosus, and Lactobacillus bacteria. The results of 5\% MDPB incorporation showed complete bactericidal effects against S. mutans in $30 \mathrm{~s}$ with a similar effect on Actinomyces viscosus, and higher effect on Lactobacillus. The article also found no adverse effect on tensile bond strength and degree of conversion. The knowledge of the effect of incorporating different concentrations of MDPB in dentin primer helps clinicians and scientists to improve the performance of dental adhesives.

The fourth most-cited article was published in 2009 (Dental Materials: Q1) by Ahn et al. [36] (146 citations), which assessed the cariogenic streptococci adhesion, growth, and diffusion after adding specific wt. \% of silica nanofillers and various ppm concentrations of silver nanoparticles into composite adhesive. The adhesion and growth of S. mutans were lower in experimental groups compared with conventional adhesives. At the same time, no inhibition zones were observed among the groups after $48 \mathrm{~h}$.

The fifth most-cited article was again published in Dental Materials (Q1) by Imazato et al. in 2006 (138 citations). The authors have compared the Clearfil Protect Bond primer (PB) with three different modified materials (PB without MDPB, PB without MDPB, and 10-methacryloyloxydecyldihydrogen phosphate (MDP), and PB without MDPB/MDP and with $1 \%$ Cetylpyridinium chloride). Antibacterial efficacy was determined against S. mutans, Lactobacillus casei, and Actinomyces naeslundii through agar disc-diffusion test, determination of minimum inhibitory/bactericidal concentrations, and assessment on bacterial-impregnated demineralized dentin blocks. The PB primer was the most effective against bacteria compared with modified materials. The knowledge of the acidity effect on antibacterial efficacy when using MDPB-containing materials can help clinicians and scientists to develop a protocol of using the material in multiple applications.

Since 2013, the trend has been shifted to publish more papers about antibacterial adhesives. This study identified the main geographic areas in the world related to publications based on antibacterial adhesive studies production. It was found that the maximum number of publications came from the USA (39.4\%), China (36\%), Brazil (23.5\%), and Japan (8.7\%). The publications on antibacterial adhesives were also observed in emerging countries, such as Turkey (5\%), Italy (3\%), South Korea (2.3\%), and Spain (2.3\%). It is anticipated that the high GDP rate and expenditures on 
R\&D might be a reason for more publications from the USA and China. The distribution of published articles shows the clear influence of economic and development levels. However, these reasons were not fully investigated in this study and beyond the scope. The growth in the number of publications in other countries such as Turkey and South Korea reflects the efforts being undertaken and their increasing presence in the international setting. The most prolific author in this area is Imazato, S. (Japan), and their four research papers are in the top 10 most cited papers, and the cumulative citation of these papers is 573 . His seven papers also appeared in the top 15 strongest citation bursts that shows the interest of researchers in his area of research.

\subsection{Preferred Journals}

The 4 out of 10 most preferred publication outlets for antibacterial adhesive publications are listed in the Q1 ranking of Web of Science; 3 of these are from the (Elsevier Sci. Ltd., Amsterdam, The Netherlands), and 1 is from the USA (Sage Publishing Inc, Thousand Oaks, CA, USA). Dental Materials is ranked first with 40 articles (15.9\%). Similarly, the Journal of Dentistry and Journal of Dental Research have published $29(11.5 \%)$ and $10(3.98 \%)$ articles, respectively. Dental Materials Journal is last in the list of highly influential journals, and $5(1.99 \%)$ articles were published in this journal. The trend is more in high impact factor journals, and most influential journals are in Q1 (4), Q2 (4), and Q3 (2) category. Out of these, an article by Imazato et al. (2003) is ranked second in the highly cited top 10 articles on antibacterial adhesives.

Similarly, six most cited articles were published in Dental Materials (Elsevier Sci. Ltd.), two in Journal of Dental Research (Sage Publishing Inc.), and one each in Journal of Dentistry (Elsevier Sci. Ltd.) and Biomaterials (Elsevier Sci. Ltd.). All these journals are from developed countries, follow rigorous peer-reviewing, and publish articles only in the English language. Secondly, the Dental Materials, Journal of Dental Research, and Journal of Dentistry are specialized journals from the Dentistry category. However, biomaterials is an interdisciplinary journal and thus publishes research from different disciplines, including biomedical materials and dentistry.

\subsection{Frequently Used Keywords and Emerging Keywords (1996-2013, 2014-2016)}

The findings in this study showed that the keywords determined the trend of publications in this area. The most frequently used keywords would help researchers look for articles relevant to antibacterial adhesives. The three-factor relationship showed that the "antibacterial" keyword was mainly used by authors from the USA and China. This particular keyword seems to be generic; however, it was used repeatedly. Less attention has been given to keywords associated with inorganic fillers with antibacterial properties such as silver, silver diamine fluoride. Furthermore, no attention has been given to those inorganic components such as zinc, magnesium, and polymeric contents having antibacterial properties. However, highly cited papers are based on MDP and MDPB based adhesives.

In thematic evaluation, it was found that keywords such as 'antibacterial activities', 'antibacterial', and 'quaternary ammonium' have been used throughout the 25 years. Similarly, 'antibacterial monomer' has been used frequently during 2014-2020. The use of these keywords might be due to the introduction of the concept of 'immobilized bactericide' in dentistry by Imazato et al. [282]. Therefore, the use of antibacterial compounds has gained interest to be used in dental adhesives. This innovative idea of developing antibacterial monomers and their use in composite resin was first given in 1993 [283]. Later, it was introduced in dental adhesives and bonding agents, and the material was commercialized (Clearfil Protect Bond, Kuraray Medical Inc, Okayama, Japan). Another keyword, which has been used frequently is 'chlorhexidine'. Many studies have shown promising results using this material and considered chlorhexidine as the most effective antibacterial material. In contrast to this, surprisingly, 'silver nanoparticle' disappeared after 2013, which could be due to discoloration of tooth structure caused by silver particles [284]. 


\subsection{International Collaboration and Authorship Patterns}

Various national and international programs have been launched in many countries to focus on promoting interdisciplinary research through research funding and grant [285]. It has become increasingly important that oral healthcare professionals should work together. The approach towards interdisciplinary collaboration can improve not only the quality of research but also inter-profession communications. A similar trend was observed in this study, where most of the publications were from authors with different backgrounds, including dentistry, material sciences, microbiology, etc. The number of multiple authors could be due to the emergence of interest among researchers in the field of antibacterial adhesives. This analysis is important to highlight the role of different researchers who can contribute to the field of antibacterial adhesives in several capacities. It is expected that in the future, more collaborative work will come, and new or innovative antibacterial agents will be introduced. Furthermore, a larger number of publications have multiple authors, and the contribution of 4-6 authors in articles have the highest TP and can be considered the most productive. This can be related to the collaboration between various institutes, countries, and researchers to expedite the development of antibacterial dental adhesives.

\subsection{Limitations and Future Research Directions}

This study has certain limitations. Albeit the researchers thoroughly tried to include all the relevant keywords to retrieve the literature, it is a possibility that few important studies might have been missed. Self-citation was not assessed in this study, as there is no standard mechanism to identify self-citation. In this study, articles indexed in Web of Science were included; other databases such as Scopus, PubMed, and Google Scholar were not included. The meeting, case report, letter, abstract, biography, editorial were not included.

Even with the limitation, the present study on antibacterial adhesives opens further opportunities for future research. Researchers from dental material sciences can formulate strategies on the topics that are developing and have gained little attention in the previous investigations. In addition, they can find the most influential papers, authors, and journals to identify the research gaps and new insights in this area. Future research directions based on this bibliometric analysis include (1) research in antibacterial adhesive needs to focus on more targeted areas i.e., antibacterial monomers, antibacterial nanoparticles, antibacterial peptides, etc.; (2) comparative research on this topic from developed and developing countries; and (3) use of more comprehensive and broader demographic variables.

\section{Conclusions}

The overall purpose of this study was to provide a comprehensive bibliographic review of the research published on antibacterial adhesives. The publication trend was divided into two ranges-i.e., 1996-2012 and 2013-2020-whereby a substantial increase in publications was found from 2013 onward on this topic. Most of the publications with the highest citations were mainly from the United States, specifically from the University of Maryland, USA. However, the trend showed that multiple authors worked together and published papers on this topic. The articles were mostly published in Dental Materials, and articles based on quaternary ammonium received the highest number of citations, whereby "quaternary ammonium", "antibacterial adhesive", and "antibacterial monomers" have been used commonly as keywords. It is expected that this quantitative bibliometric study will provide a direction to researchers, funding organizations, and policy makers about strength and missing gaps in the antibacterial dental adhesives field. 
Author Contributions: Conceptualization, A.S.K. and S.U.R.; Methodology, S.U.R., S.A., and M.A.; Software, S.U.R. and M.A.; Validation, A.S.K. and S.U.R.; Formal analysis, S.U.R. and Y.K.A.; Investigation, S.A., M.A., and M.K.; Resources, S.A.; Data curation, S.U.R., M.A., and S.A.; Writing-original draft preparation, Y.K.A., M.K., S.U.R., and A.S.K.; Writing-review and editing, A.S.K., M.K., and S.U.R.; Visualization, A.S.K. and S.U.R.; Supervision, A.S.K., and S.U.R.; Project administration, A.S.K. and S.U.R.; Funding acquisition, S.A. All authors have read and agreed to the published version of the manuscript.

Funding: The authors would like to acknowledge the support of Prince Sultan University for paying the Article Processing Charges (APC) of this publication.

Conflicts of Interest: The authors declare no conflict of interest. The funders had no role in the design of the study, in the collection, analyses, or interpretation of data, in the writing of the manuscript, or in the decision to publish the results.

\section{References}

1. Bedran-Russo, A.; Leme-Kraus, A.A.; Vidal, C.M.; Teixeira, E.C. An Overview of Dental Adhesive Systems and the Dynamic Tooth-Adhesive Interface. Dent. Clin. 2017, 61, 713-731. [CrossRef] [PubMed]

2. Florez, F.L.E.; Trofimov, A.A.; Ievlev, A.; Qian, S.; Rondinone, A.J.; Khajotia, S.S. Advanced characterization of surface-modified nanoparticles and nanofilled antibacterial dental adhesive resins. Sci. Rep. 2020, 10, 1-12.

3. Sofan, E.; Sofan, A.; Palaia, G.; Tenore, G.; Romeo, U.; Migliau, G. Classification review of dental adhesive systems: From the IV generation to the universal type. Ann. Stomatol. 2017, 8, 1-17. [CrossRef]

4. Van Meerbeek, B.; Yoshihara, K.; Van Landuyt, K.; Yoshida, Y.; Peumans, M. From Buonocore's Pioneering Acid-Etch Technique to Self-Adhering Restoratives. A Status Perspective of Rapidly Advancing Dental Adhesive Technology. J. Adhes. Dent. 2020, 22, 7-34. [CrossRef] [PubMed]

5. Khan, A.S.; Syed, M.R. A review of bioceramics-based dental restorative materials. Dent. Mater. J. 2019, 38, 163-176. [CrossRef] [PubMed]

6. Zhang, J.; Zhao, Y.; Tian, Z.; Zhu, J.; Shi, Z.; Cui, Z.; Zhu, S. Enhancement performance of application mussel-biomimetic adhesive primer for dentin adhesives. RSC Adv. 2020, 10, 12035-12046. [CrossRef]

7. Khvostenko, D.; Hilton, T.; Ferracane, J.; Mitchell, J.; Kruzic, J. Bioactive glass fillers reduce bacterial penetration into marginal gaps for composite restorations. Dent. Mater. 2016, 32, 73-81. [CrossRef]

8. Cadenaro, M.; Maravic, T.; Comba, A.; Mazzoni, A.; Fanfoni, L.; Hilton, T.; Ferracane, J.; Breschi, L. The role of polymerization in adhesive dentistry. Dent. Mater. 2019, 35, e1-e22. [CrossRef]

9. Maroulakos, G.; He, J.; Nagy, W.W. The Post-endodontic Adhesive Interface: Theoretical Perspectives and Potential Flaws. J. Endod. 2018, 44, 363-371. [CrossRef]

10. Yan, H.; Wang, S.; Han, L.; Peng, W.; Yi, L.; Guo, R.; Liu, S.; Yang, H.; Huang, C. Chlorhexidine-encapsulated mesoporous silica-modified dentin adhesive. J. Dent. 2018, 78, 83-90. [CrossRef]

11. Tammaro, L.; Salle, A.D.; Calarco, A.; Luca, I.; Riccitiello, F.; Peluso, G.; Vittoria, V.; Sorrentino, A. Multifunctional Bioactive Resin for Dental Restorative Materials. Polymers 2020, 12, 332. [CrossRef] [PubMed]

12. Jiao, Y.; Tay, F.R.; Niu, L.-N.; Chen, J.-H. Advancing antimicrobial strategies for managing oral biofilm infections. Int. J. Oral Sci. 2019, 11,1-11. [CrossRef] [PubMed]

13. Chrószcz, M.; Barszczewska-Rybarek, I. Nanoparticles of Quaternary Ammonium Polyethylenimine Derivatives for Application in Dental Materials. Polymers 2020, 12, 2551. [CrossRef] [PubMed]

14. Demarco, F.F.; Collares, K.; Correa, M.B.; Cenci, M.S.; Moraes, R.R.; Opdam, N.J. Should my composite restorations last forever? Why are they failing? Braz. Oral Res. 2017, 31, e56. [CrossRef] [PubMed]

15. Chen, L.; Suh, B.; Yang, J. Antibacterial dental restorative materials: A review. Am. J. Dent. 2018, 31, 6B-12B.

16. Ferrando-Magraner, E.; Bellot-Arcís, C.; Paredes-Gallardo, V.; Almerich-Silla, J.M.; García-Sanz, V.; Fernández-Alonso, M. Antibacterial properties of nanoparticles in dental restorative materials. A systematic review and meta-analysis. Medicina 2020, 56, 55. [CrossRef]

17. Lung, C.Y.K.; Sarfraz, Z.; Habib, A.; Khan, A.S.; Matinlinna, J.P. Effect of silanization of hydroxyapatite fillers on physical and mechanical properties of a bis-GMA based resin composite. J. Mech. Behav. Biomed. Mater. 2016, 54, 283-294. [CrossRef]

18. Hussain, N.; Khalid, H.; AlMaimouni, Y.K.; Ikram, S.; Khan, M.; Din, S.U.; Talal, A.; Khan, A.S. Microwave assisted urethane grafted nano-apatites for dental adhesives. J. Bioact. Compat. Polym. 2020, 35, 479-490. [CrossRef] 
19. Makvandi, P.; Jamaledin, R.; Jabbari, M.; Nikfarjam, N.; Borzacchiello, A. Antibacterial quaternary ammonium compounds in dental materials: A systematic review. Dent. Mater. 2018, 34, 851-867. [CrossRef]

20. Imazato, S.; Ebi, N.; Takahashi, Y.; Kaneko, T.; Ebisu, S.; Russell, R.R. Antibacterial activity of bactericide-immobilized filler for resin-based restoratives. Biomaterials 2003, 24, 3605-3609. [CrossRef]

21. Betancourt, D.; Baldion, P.; Castellanos, J.E. Resin-dentin bonding interface: Mechanisms of degradation and strategies for stabilization of the hybrid layer. Int. J. Biomater. 2019, 2019, 5268342. [CrossRef] [PubMed]

22. Fujimura, Y.; Weerasinghe, D.; Kawashima, M. Development of an antibacterial bioactive dental adhesive: Simplicity and innovation. Am. J. Dent. 2018, 31, 13B-16B. [PubMed]

23. Collares, F.M.; Garcia, I.M.; Klein, M.; Parolo, C.F.; Sánchez, F.A.L.; Takimi, A.; Bergmann, C.P.; Samuel, S.M.W.; Melo, M.A.; Leitune, V.C. Exploring Needle-Like Zinc Oxide Nanostructures for Improving Dental Resin Sealers: Design and Evaluation of Antibacterial, Physical and Chemical Properties. Polymers 2020, 12, 789. [CrossRef] [PubMed]

24. Dias, P.G.; Da Silva, E.M.; Carvalho, C.; Miranda, M.; Portela, M.B.; Amaral, C.M. Characterization and Antibacterial Effect of an Experimental Adhesive Containing Different Concentrations of Proanthocyanidin. J. Adhes. Dent. 2020, 22, 139-147.

25. Garcia, I.M.; Souza, V.S.; Scholten, J.D.; Collares, F.M. Quantum Dots of Tantalum Oxide with an Imidazolium Ionic Liquid as Antibacterial Agent for Adhesive Resin. J. Adhes. Dent. 2020, 22, 207-214.

26. Cruzetta, L.; Garcia, I.M.; de Souza Balbinot, G.; Motta, A.S.; Collares, F.M.; Sauro, S.; CB Leitune, V. Evaluation of the Physicochemical and Antibacterial Properties of Experimental Adhesives Doped with Lithium Niobate. Polymers 2020, 12, 1330. [CrossRef]

27. Cocco, A.R.; Da Rosa, W.L.d.O.; Da Silva, A.F.; Lund, R.G.; Piva, E. A systematic review about antibacterial monomers used in dental adhesive systems: Current status and further prospects. Dent. Mater. 2015, 31, 1345-1362. [CrossRef]

28. Shafiei, F.; Memarpour, M. Antibacterial activity in adhesive dentistry: A literature review. Gen. Dent. 2012, 60, e346-e356.

29. Shaikh, M.S.; Ullah, R.; Lone, M.A.; Matabdin, H.; Khan, F.; Zafar, M.S. Periodontal regeneration: A bibliometric analysis of the most influential studies. Regen. Med. 2019, 14, 1121-1136. [CrossRef]

30. Tahim, A.; Bansal, H.; Goodson, A.M.C.; Payne, K.F.B.; Sabharwal, S. Open Access Publishing: A Study of Current Practice in Oral and Maxillofacial Surgery Research. J. Maxillofac. Oral Surg. 2016, 15, 517-520. [CrossRef]

31. Tarazona, B.; Vidal-Infer, A.; Alonso-Arroyo, A. Bibliometric analysis of the scientific production in implantology (2009-2013). Clin. Oral Implants. Res. 2017, 28, 864-870. [CrossRef] [PubMed]

32. Prevezanos, P.; Tsolakis, A.I.; Christou, P. Highly cited orthodontic articles from 2000 to 2015. Am. J. Orthod. Dentofac. Orthop. 2018, 153, 61-69. [CrossRef] [PubMed]

33. Thornton, K.; Lee, D.J.; Yuan, J.C.-C.; Knoernschild, K.L.; Campbell, S.D.; Sukotjo, C. An Analysis of Prosthodontic Research Productivity: Geographic, Economic, and Collaborative Perspective. J. Prosthodont. 2012, 21, 73-78. [CrossRef] [PubMed]

34. Poletto, V.C.; Faraco Junior, I.M. Bibliometric study of articles published in a Brazilian journal of pediatric dentistry. Braz. Oral Res. 2010, 24, 83-88. [CrossRef] [PubMed]

35. Adnan, S.; Ullah, R. Top-cited articles in regenerative endodontics: A bibliometric analysis. J. Endod. 2018, 44, 1650-1664. [CrossRef]

36. Ahn, S.J.; Lee, S.J.; Kook, J.K.; Lim, B.S. Experimental antimicrobial orthodontic adhesives using nanofillers and silver nanoparticles. Dent. Mater. 2009, 25, 206-213. [CrossRef]

37. Ajami, A.A.; Rikhtegaran, S.; Bahari, M.; Hamadanchi, S. Antibacterial activity of self-adhesive resin cements against Streptococcus mutans at different time intervals. Iran. J. Microbiol. 2019, 11, 313-319. [CrossRef]

38. Alghanem, A.; Fernandes, G.; Visser, M.; Dziak, R.; Renne, W.G.; Sabatini, C. Biocompatibility and bond degradation of poly-acrylic acid coated copper iodide-adhesives. Dent. Mater. 2017, 33, E336-E347. [CrossRef]

39. Almaroof, A.; Niazi, S.A.; Rojo, L.; Mannocci, F.; Deb, S. Evaluation of dental adhesive systems incorporating an antibacterial monomer eugenyl methacrylate (EgMA) for endodontic restorations. Dent. Mater. 2017, 33, E239-E254. [CrossRef]

40. Al-Musallam, T.A.; Evans, C.A.; Drummond, J.L.; Matasa, C.; Wu, C.D. Antimicrobial properties of an orthodontic adhesive combined with cetylpyridinium chloride. Am. J. Orthod. Dentofac. Orthop. 2006, 129, 245-251. [CrossRef] 
41. Al-Qarni, F.D.; Tay, F.; Weir, M.D.; Melo, M.A.S.; Sun, J.R.; Oates, T.W.; Xie, X.J.; Xu, H.H.K. Protein-repelling adhesive resin containing calcium phosphate nanoparticles with repeated ion-recharge and re-releases. J. Dent. 2018, 78, 91-99. [CrossRef] [PubMed]

42. Altmann, A.S.P.; Collares, F.M.; Balbinot, G.D.; Leitune, V.C.B.; Takimi, A.S.; Samuel, S.M.W. Niobium pentoxide phosphate invert glass as a mineralizing agent in an experimental orthodontic adhesive. Angle Orthod. 2017, 87, 759-773. [CrossRef] [PubMed]

43. Andrade, V.; Martinez, A.; Rojas, N.; Bello-Toledo, H.; Flores, P.; Sanchez-Sanhueza, G.; Catalan, A. Antibacterial activity against Streptococcus mutans and diametrical tensile strength of an interim cement modified with zinc oxide nanoparticles and terpenes: An in vitro study. J. Prosthet. Dent. 2018, $119,7$. [CrossRef] [PubMed]

44. Andre, C.B.; Gomes, B.; Duque, T.M.; Rosalen, P.L.; Chan, D.C.N.; Ambrosano, G.M.B.; Giannini, M. Antimicrobial activity, effects on Streptococcus mutans biofilm and interfacial bonding of adhesive systems with and without antibacterial agent. Int. J. Adhes. Adhes. 2017, 72, 123-129. [CrossRef]

45. Andre, C.B.; Rosalen, P.L.; Galvao, L.; Fronza, B.M.; Ambrosano, G.M.B.; Ferracane, J.L.; Giannini, M. Modulation of Streptococcus mutans virulence by dental adhesives containing anti-caries agents. Dent. Mater. 2017, 33, 1084-1092. [CrossRef]

46. Andriani, A.; Purwanegara, M.K. Effect of titanium dioxide nanoparticle addition into orthodontic adhesive resin on enamel microhardness. In 1st Physics and Technologies in Medicine and Dentistry Symposium; IoP Publishing Ltd.: Bristol, UK, 2017; Volume 884.

47. Arjmand, N.; Boruziniat, A.; Zakeri, M.; Mohammadipour, H.S. Microtensile bond strength of resin cement primer containing nanoparticles of silver (NAg) and amorphous calcium phosphate (NACP) to human dentin. J. Adv. Prosthodont. 2018, 10, 177-183. [CrossRef]

48. Baena, E.; Cunha, S.R.; Maravic, T.; Comba, A.; Paganelli, F.; Alessandri-Bonetti, G.; Ceballos, L.; Tay, F.R.; Breschi, L.; Mazzoni, A. Effect of Chitosan as a Cross-Linker on Matrix Metalloproteinase Activity and Bond Stability with Different Adhesive Systems. Mar. Drugs 2020, 18, 263. [CrossRef]

49. Bakhsh, T.A. Effect of Silver-Nitrate on interfacial gap detection under polymeric dental restoration in CP-OCT imaging. In Medical Imaging 2019: Biomedical Applications in Molecular, Structural, and Functional Imaging; Gimi, B., Krol, A., Eds.; Spie-Int Soc Optical Engineering: Bellingham, WA, USA, 2019; Volume 10953.

50. Banzi, E.C.F.; Costa, A.R.; Puppin-Rontani, R.M.; Babu, J.; Garcia-Godoy, F. Inhibitory effects of a cured antibacterial bonding system on viability and metabolic activity of oral bacteria. Dent. Mater. 2014, 30, E238-E244. [CrossRef]

51. Basting, R.T.; Goncalves, F.R.; Franca, F.M.G.; Do Amaral, F.L.B.; Florio, F.M. Antimicrobial Potential of Papain Chemomechanical Agent on Streptococcus Mutans and Lactobacillus Casei Followed by the Use of Self-Etching Adhesive Systems. J. Clin. Pediatr. Dent. 2016, 40, 62-68. [CrossRef]

52. Bauer, J.; Silva, A.S.E.; Carvalho, E.M.; Carvalho, C.N.; Carvalho, R.M.; Manso, A.P. A niobophosphate bioactive glass suspension for rewetting dentin: Effect on antibacterial activity, $\mathrm{pH}$ and resin-dentin bonding durability. Int. J. Adhes. Adhes. 2018, 84, 178-183. [CrossRef]

53. Bessudnova, N.O.; Bilenko, D.I.; Venig, S.B.; Atkin, V.S.; Zakharevich, A.M. A new X-ray adhesive system with embedded nano-particulate silver markers for dental applications. In Saratov Fall Meeting 2012: Optical Technologies in Biophysics and Medicine XIV; and Laser Physics and Photonics XIV; Tuchin, V.V., Genina, E.A., Derbov, V.L., Meglinski, I.V., Eds.; Spie-Int Soc Optical Engineering: Bellingham, WA, USA, 2013; Volume 8699.

54. Bessudnova, N.O.; Bilenko, D.I.; Venig, S.B.; Shlyapnikova, O.A. Mechanical Properties of Adhesive System with a Silver Nanoparticulate Filler: An Experimental Study. In Saratov Fall Meeting 2013: Optical Technologies in Biophysics and Medicine XV; and Laser Physics and Photonics XV; Genina, E.A., Derbov, V.L., Meglinski, I., Tuchin, V.V., Eds.; Spie-Int Soc Optical Engineering: Bellingham, WA, USA, 2014; Volume 9031.

55. Beyth, N.; Yudovin-Farber, I.; Bahir, R.; Domb, A.J.; Weissa, E.I. Antibacterial activity of dental composites containing quaternary ammonium polyethylenimine nanoparticles against Streptococcus mutans. Biomaterials 2006, 27, 3995-4002. [CrossRef] [PubMed]

56. Bienek, D.R.; Giuseppetti, A.A.; Okeke, U.C.; Frukhtbeyn, S.A.; Dupree, P.J.; Khajotia, S.S.; Florez, F.L.E.; Hiers, R.D.; Skrtic, D. Antimicrobial, biocompatibility, and physicochemical properties of novel adhesive methacrylate dental monomers. J. Bioact. Compat. Polym. 2020, 35, 160-173. [CrossRef]

57. Boutsiouki, C.; Franizenberger, R.; Lucker, S.; Kramer, N. Inhibition of secondary caries in vitro by addition of chlorhexidine to adhesive components. Dent. Mater. 2019, 35, 422-433. [CrossRef] [PubMed] 
58. Brambilla, E.; Ionescu, A.; Mazzoni, A.; Cadenaro, M.; Gagliani, M.; Ferraroni, M.; Tay, F.; Pashley, D.; Breschi, L. Hydrophilicity of dentin bonding systems influences in vitro Streptococcus mutans biofilm formation. Dent. Mater. 2014, 30, 926-935. [CrossRef] [PubMed]

59. Bregnocchi, A.; Zanni, E.; Uccelletti, D.; Marra, F.; Cavallini, D.; De Angelis, F.; De Bellis, G.; Bossu, M.; Ierardo, G.; Polimeni, A.; et al. Graphene-based dental adhesive with anti-biofilm activity. J. Nanobiotechnol. 2017, 15, 13. [CrossRef] [PubMed]

60. Breschi, L.; Cammelli, F.; Visintini, E.; Mazzoni, A.; Vita, F.; Carrilho, M.; Cadenaro, M.; Foulger, S.; Mazzoti, G.; Tay, F.R.; et al. Influence of Chlorhexidine Concentration on the Durability of Etch-and-Rinse Dentin Bonds: A 12-month In Vitro Study. J. Adhes. Dent. 2009, 11, 191-198. [PubMed]

61. Bridi, E.C.; Amaral, F.L.B.; Franca, F.M.G.; Turssi, C.P.; Florio, F.M.; Basting, R.T. In Vitro Effects of $2.5 \%$ Titanium Tetrafluoride on Streptococcus Mutans and Lactobacillus Casei in Dentin Followed by Self-Etching Adhesive Systems. Eur. J. Prosthodont. Restor. Dent. 2015, 23, 179-186. [CrossRef] [PubMed]

62. Bulut, H.; Turkun, M.; Turkun, L.S.; Isiksal, E. Evaluation of the shear bond strength of 3 curing bracket bonding systems combined with an antibacterial adhesive. Am. J. Orthod. Dentofac. Orthop. 2007, 132, 77-83. [CrossRef]

63. Cai, Y.L.; Stromme, M.; Melhus, A.; Engqvist, H.; Welch, K. Photocatalytic inactivation of biofilms on bioactive dental adhesives. J. Biomed. Mater. Res. Part B 2014, 102, 62-67. [CrossRef]

64. Cal, E.; Turkun, L.S.; Turkun, M.; Toman, M.; Toksavul, S. Effect of an antibacterial adhesive on the bond strength of three different luting resin composites. J. Dent. 2006, 34, 372-380. [CrossRef]

65. Cao, L.; Wu, J.L.; Zhang, Q.; Baras, B.; Bhadila, G.; Li, Y.C.; Melo, M.A.S.; Weir, M.D.; Bai, Y.X.; Zhang, N.; et al. Novel Protein-Repellent and Antibacterial Resins and Cements to Inhibit Lesions and Protect Teeth. Int. J. Polym. Sci. 2019. [CrossRef]

66. Carvalho, F.G.; Carlo, H.L.; Sacramento, P.A.; De Barros, S.; Santos, R.L.; Puppin-Rontani, R.M. Biodegradation of caries-affected dentin bonding interface of fluoride and MDPB-containing adhesive system. Int. J. Adhes. Adhes. 2013, 47, 134-140. [CrossRef]

67. Cehreli, Z.C.; Atac, A.S.; Sener, B. Antimicrobial properties of self-etching primer bonding systems. Oper. Dent. 2003, 28, 143-148. [PubMed]

68. Chai, Z.; Li, F.; Fang, M.; Wang, Y.; Ma, S.; Xiao, Y.; Huang, L.; Chen, J. The bonding property and cytotoxicity of a dental adhesive incorporating a new antibacterial monomer. J. Oral Rehabil. 2011, 38, 849-856. [CrossRef]

69. Chen, C.; Cheng, L.; Weir, M.D.; Lin, N.J.; Lin-Gibson, S.; Zhou, X.D.; Xu, H.H.K. Primer containing dimethylaminododecyl methacrylate kills bacteria impregnated in human dentin blocks. Int. J. Oral Sci. 2016, 8, 239-245. [CrossRef]

70. Chen, C.; Weir, M.D.; Cheng, L.; Lin, N.J.; Lin-Gibson, S.; Chow, L.C.; Zhou, X.D.; Xu, H.H.K. Antibacterial activity and ion release of bonding agent containing amorphous calcium phosphate nanoparticles. Dent. Mater. 2014, 30, 891-901. [CrossRef]

71. Cheng, L.; Weir, M.D.; Zhang, K.; Arola, D.D.; Zhou, X.D.; Xu, H.H.K. Dental primer and adhesive containing a new antibacterial quaternary ammonium monomer dimethylaminododecyl methacrylate. J. Dent. 2013, 41, 345-355. [CrossRef]

72. Cheng, L.; Zhang, K.; Melo, M.A.S.; Weir, M.D.; Zhou, X.; Xu, H.H.K. Anti-biofilm Dentin Primer with Quaternary Ammonium and Silver Nanoparticles. J. Dent. Res. 2012, 91, 598-604. [CrossRef]

73. Cheng, L.; Zhang, K.; Weir, M.D.; Liu, H.B.; Zhou, X.D.; Xu, H.H.K. Effects of antibacterial primers with quaternary ammonium and nano-silver on Streptococcus mutans impregnated in human dentin blocks. Dent. Mater. 2013, 29, 462-472. [CrossRef]

74. Cheng, L.; Zhang, K.; Zhang, N.; Melo, M.A.S.; Weir, M.D.; Zhou, X.D.; Bai, Y.X.; Reynolds, M.A.; Xu, H.H.K. Developing a New Generation of Antimicrobial and Bioactive Dental Resins. J. Dent. Res. 2017, 96, 855-863. [CrossRef]

75. Cheng, L.; Zhang, K.; Zhou, C.C.; Weir, M.D.; Zhou, X.D.; Xu, H.H.K. One-year water-ageing of calcium phosphate composite containing nano-silver and quaternary ammonium to inhibit biofilms. Int. J. Oral Sci. 2016, 8, 172-181. [CrossRef] [PubMed]

76. Cocco, A.R.; Da Rosa, W.L.D.; Peralta, S.L.; Maske, T.T.; da Silva, A.F.; Hartwig, C.A.; Mesko, M.F.; Piva, E.; Lund, R.G. New adhesive system based in metals cross-linking methacrylate. J. Mech. Behav. Biomed. Mater. 2018, 77, 519-526. [CrossRef] [PubMed] 
77. Cocco, A.R.; Maske, T.T.; Lund, R.G.; Moraes, R.R. The antibacterial and physicochemical properties of a one-step dental adhesive modified with potential antimicrobial agents. Int. J. Adhes. Adhes. 2016, 71, 74-80. [CrossRef]

78. Costa, J.F.; Siqueira, W.L.; Loguercio, A.D.; Reis, A.; De Oliveira, E.; Alves, C.M.C.; Bauer, J.R.D.; Grande, R.H.M. Characterization of aqueous silver nitrate solutions for leakage tests. J. Appl. Oral Sci. 2011, 19, 254-259. [CrossRef]

79. Da Silva, B.; Franca, F.M.G.; Florio, F.M.; Basting, R.T. In situ anticariogenic effect of adhesive systems containing fluoride and MDPB. Am. J. Dent. 2010, 23, 75-80.

80. de Carvalho, F.G.; Puppin-Rontani, J.; Dos Santos, R.L.; Carlo, H.L.; Bonan, P.R.F.; Garcia-Godoy, F.; Puppin-Rontani, R.M. In vitro effect of S-mutans biofilm on fluoride/MDPB-containing adhesive system bonded to caries-affected primary dentin. Am. J. Dent. 2014, 27, 227-232.

81. De Carvalho, F.G.; Puppin-Rontani, R.M.; De Fucio, S.B.P.; Negrini, T.D.; Carlo, H.L.; Garcia-Godoy, F. Analysis by confocal laser scanning microscopy of the MDPB bactericidal effect on S. mutans biofilm CLSM analysis of MDPB bactericidal effect on biofilm. J. Appl. Oral Sci. 2012, 20, 568-575. [CrossRef]

82. De Siqueira, F.S.F.; Morales, L.A.R.; Granja, M.C.P.; De Melo, B.D.; Monteiro-Neto, V.; Reis, A.; Cardenas, A.F.M.; Loguercio, A.D. Effect of Silver Diamine Fluoride on the Bond in Properties to Caries-affected Dentin. J. Adhes. Dent. 2020, 22, 161-172. [CrossRef]

83. Decha, N.; Talungchi, S.; Iawsipo, P.; Pikuingam, A.; Saiprasert, P.; Tansakul, C. Synthesis and characterization of new hydrolytic-resistant dental resin adhesive monomer HMTAF. Des. Monomers Polym. 2019, 22, 106-113. [CrossRef]

84. Degrazia, F.W.; Altmann, A.S.P.; Ferreira, C.J.; Arthur, R.A.; Leitune, V.C.B.; Samuel, S.M.W.; Collares, F.M. Evaluation of an antibacterial orthodontic adhesive incorporated with niobium-based bioglass: An in situ study. Braz. Oral Res. 2019, 33, 11. [CrossRef]

85. Degrazia, F.W.; Leitune, V.C.B.; Garcia, I.M.; Arthur, R.A.; Samuel, S.M.W.; Collares, F.M. Effect of silver nanoparticles on the physicochemical and antimicrobial properties of an orthodontic adhesive. J. Appl. Oral Sci. 2016, 24, 404-410. [CrossRef] [PubMed]

86. Delauiz, Y.; Liu, T.W.; Deonarain, A.R.; Finer, Y.; Sholzati, B.; Santerre, J.P. Physical properties and cytotoxicity of antimicrobial dental resin adhesives containing dimethacrylate oligomers of Ciprofloxacin and Metronidazole. Dent. Mater. 2019, 35, 229-243. [CrossRef] [PubMed]

87. Demirel, G.; Eryilmaz, M.; Seberol, H.; Gur, G. In vitro antibacterial activity of self-etch bio-active dental adhesives after artificial aging. Eur. Oral Res. 2019, 53, 32-37. [CrossRef] [PubMed]

88. Deng, D.; Huang, X.; Huang, C.; Yang, T.; Du, X.; Wang, Y.; Ouyang, X.; Pei, D. Effects of chlorhexidine on bonding durability of different adhesive systems using a novel thermocycling method. Aust. Dent. J. 2013, 58, 148-155. [CrossRef]

89. Deng, S.; Chung, K.H.; Chan, D.C.N.; Spiekerman, C. Evaluation of Bond Strength and Microleakage of a Novel Metal-titanate Antibacterial Agent. Oper. Dent. 2016, 41, E48-E56. [CrossRef]

90. dos Santos, A.; Andre, C.B.; Martim, G.C.; Schuquel, I.T.A.; Pfeifer, C.S.; Ferracane, J.L.; Tominaga, T.T.; Khalil, N.M.; Radovanovic, E.; Girotto, E.M. Methacrylate saccharide-based monomers for dental adhesive systems. Int. J. Adhes. Adhes. 2018, 87, 1-11. [CrossRef]

91. Du, X.J.; Huang, X.Q.; Huang, C.; Wang, Y.K.; Zhang, Y.F. Epigallocatechin-3-gallate (EGCG) enhances the therapeutic activity of a dental adhesive. J. Dent. 2012, 40, 485-492. [CrossRef]

92. Dutra-Correa, M.; Leite, A.; de Cara, S.; Diniz, I.M.A.; Marques, M.M.; Suffredini, I.B.; Fernandes, M.S.; Toma, S.H.; Araki, K.; Medeiros, I.S. Antibacterial effects and cytotoxicity of an adhesive containing low concentration of silver nanoparticles. J. Dent. 2018, 77, 66-71. [CrossRef]

93. Elsaka, S.E. Antibacterial activity and adhesive properties of a chitosan-containing dental adhesive. Quintessence Int. 2012, 43, 603-613.

94. Eminkahyagil, N.; Korkmaz, Y.; Gokalp, S.; Baseren, M. Shear bond strength of orthodontic brackets with newly developed antibacterial self-etch adhesive. Angle Orthod. 2005, 75, 843-848.

95. Feitosa, S.A.; Palasuk, J.; Kamocki, K.; Geraldeli, S.; Gregory, R.L.; Platt, J.A.; Windsor, L.J.; Bottino, M.C. Doxycycline-Encapsulated Nanotube-Modified Dentin Adhesives. J. Dent. Res. 2014, 93, 1270-1276. [CrossRef] [PubMed] 
96. Feng, X.D.; Zhang, N.; Xu, H.H.K.; Weir, M.D.; Melo, M.A.S.; Bai, Y.X.; Zhang, K. Novel orthodontic cement containing dimethylaminohexadecyl methacrylate with strong antibacterial capability. Dent. Mater. J. 2017, 36, 669-676. [CrossRef] [PubMed]

97. Fernandes, G.; Renne, W.G.; Visser, M.B.; Sabatini, C. Esterase Inhibition and Copper Release from Copper Iodide Dental Adhesives-An In Vitro Study. J. Adhes. Dent. 2020, 22, 265-274. [CrossRef] [PubMed]

98. Feuerstein, O.; Matalon, S.; Slutzky, H.; Weiss, E.I. Antibacterial properties of self-etching dental adhesive systems. J. Am. Dent. Assoc. 2007, 138, 349-354. [CrossRef] [PubMed]

99. Fik, C.P.; Konieczny, S.; Pashley, D.H.; Waschinski, C.J.; Ladisch, R.S.; Salz, U.; Bock, T.; Tiller, J.C. Telechelic Poly(2-oxazoline)s with a Biocidal and a Polymerizable Terminal as Collagenase Inhibiting Additive for Long-Term Active Antimicrobial Dental Materials. Macromol. Biosci. 2014, 14, 1569-1579. [CrossRef]

100. Florez, F.L.E.; Hiers, R.D.; Larson, P.; Johnson, M.; O’Rear, E.; Rondinone, A.J.; Khajotia, S.S. Antibacterial dental adhesive resins containing nitrogen -doped titanium dioxide nanoparticles. Mater. Sci. Eng. C Mater. Biol. Appl. 2018, 93, 931-943. [CrossRef]

101. Florez, F.L.E.; Hiers, R.D.; Zhao, Y.; Merritt, J.; Rondinone, A.J.; Khajotia, S.S. Optimization of a real-time high-throughput assay for assessment of Streptococcus mutans metabolism and screening of antibacterial dental adhesives. Dent. Mater. 2020, 36, 353-365. [CrossRef]

102. Frolov, G.A.; Karasenkov, Y.N.; Gusev, A.A.; Zakharova, O.V.; Godymchuk, A.Y.; Kuznetsov, D.V.; Latuta, N.V.; Leont'ev, V.K. Germicidal Adhesives with Nanoparticles of Metals for Prevention of Recurrence of Caries. Nano Hybrids Compos. 2017, 13, 39-46. [CrossRef]

103. Fu, D.J.; Lu, Y.; Gao, S.H.; Peng, Y.J.; Duan, H.Y. Chemical Property and Antibacterial Activity of Metronidazoledecorated Ti through Adhesive Dopamine. J. Wuhan Univ. Technol. Mater. Sci. Ed. 2019, 34, 968-972. [CrossRef]

104. Fugolin, A.P.; Dobson, A.; Huynh, V.; Mbiya, W.; Navarro, O.; Franca, C.M.; Logan, M.; Merritt, J.L.; Ferracane, J.L.; Pfeifer, C.S. Antibacterial, ester-free monomers: Polymerization kinetics, mechanical properties, biocompatibility and anti-biofilm activity. Acta Biomater. 2019, 100, 132-141. [CrossRef]

105. Gao, L.; Xie, X.J.; Wang, B.; Weir, M.D.; Oates, T.W.; Xu, H.H.K.; Zhang, N.; Bai, Y.X. Protein-repellent and antibacterial effects of a novel polymethyl methacrylate resin. J. Dent. 2018, 79, 39-45. [CrossRef]

106. Garcia, I.M.; Ferreira, C.J.; De Souza, V.S.; Leitune, V.C.B.; Samuel, S.M.W.; Balbinot, G.D.; Da Motta, A.D.; Visioli, F.; Scholten, J.D.; Collares, F.M. Ionic liquid as antibacterial agent for an experimental orthodontic adhesive. Dent. Mater. 2019, 35, 1155-1165. [CrossRef] [PubMed]

107. Garcia, I.M.; Leitune, V.C.B.; Visioli, F.; Samuel, S.M.W.; Collares, F.M. Influence of zinc oxide quantum dots in the antibacterial activity and cytotoxicity of an experimental adhesive resin. J. Dent. 2018, 73, 57-60. [CrossRef] [PubMed]

108. Garcia, I.M.; Rodrigues, S.B.; Balbinot, G.D.; Visioli, F.; Leitune, V.C.B.; Collares, F.M. Quaternary ammonium compound as antimicrobial agent in resin-based sealants. Clin. Oral Investig. 2020, 24, 777-784. [CrossRef] [PubMed]

109. Ge, Y.; Ren, B.; Zhou, X.D.; Xu, H.H.K.; Wang, S.P.; Li, M.Y.; Weir, M.D.; Feng, M.Y.; Cheng, L. Novel Dental Adhesive with Biofilm-Regulating and Remineralization Capabilities. Materials 2017, 10, 26. [CrossRef]

110. Genari, B.; Leitune, V.C.B.; Jornada, D.S.; Aldrigui, B.R.; Pohlmann, A.R.; Guterres, S.S.; Samuel, S.M.W.; Collares, F.M. Effect on adhesion of a nanocapsules-loaded adhesive system. Braz. Oral Res. 2018, $32,7$. [CrossRef]

111. Genari, B.; Leitune, V.C.B.; Jornada, D.S.; Camassola, M.; Arthur, R.A.; Pohlmann, A.R.; Guterres, S.S.; Collares, F.M.; Samuel, S.M.W. Antimicrobial effect and physicochemical properties of an adhesive system containing nanocapsules. Dent. Mater. 2017, 33, 735-742. [CrossRef]

112. Geraldeli, S.; Soares, E.F.; Alvarez, A.J.; Farivar, T.; Shields, R.C.; Sinhoreti, M.A.C.; Nascimento, M.M. A new arginine-based dental adhesive system: Formulation, mechanical and anti-caries properties. J. Dent. 2017, 63, 72-80. [CrossRef]

113. Giammanco, G.M.; Cumbo, E.M.G.; Luciani, A.; Gallina, G.; Mammina, C.; Pizzo, G. In vitro evaluation of the antibacterial activity of cured dentin/enamel adhesive incorporating the antimicrobial agent MDPB. New Microbiol. 2009, 32, 385-390.

114. Godoy-Gallardo, M.; Mas-Moruno, C.; Fernandez-Calderon, M.C.; Perez-Giraldo, C.; Manero, J.M.; Albericio, F.; Gil, F.J.; Rodriguez, D. Covalent immobilization of hLf1-11 peptide on a titanium surface reduces bacterial adhesion and biofilm formation. Acta Biomater. 2014, 10, 3522-3534. [CrossRef] 
115. Gokcen, E.Y.; Oz, F.T.; Ozcelik, B.; Orhan, A.I.; Ozgul, B.M. Assessment of antibacterial activity of different treatment modalities in deciduous teeth: An in vitro study. Biotechnol. Biotechnol. Equip. 2016, 30, 1192-1198. [CrossRef]

116. Gou, Y.P.; Li, J.Y.; Meghil, M.M.; Cutler, C.W.; Xu, H.H.K.; Tay, F.R.; Niu, L.N. Quaternary ammonium silane-based antibacterial and anti-proteolytic cavity cleanser. Dent. Mater. 2018, 34, 1814-1827. [CrossRef] [PubMed]

117. Gou, Y.P.; Meghil, M.M.; Pucci, C.R.; Breschi, L.; Pashley, D.H.; Cutler, C.W.; Niu, L.N.; Li, J.Y.; Tay, F.R. Optimizing resin-dentin bond stability using a bioactive adhesive with concomitant antibacterial properties and anti-proteolytic activities. Acta Biomater. 2018, 75, 171-182. [CrossRef] [PubMed]

118. Gumustas, B.; Dosdogru, E.Y.; Guneysu, S. Evaluation of mechanical properties of fluoride-releasing dental materials after multiple fluoride recharge/discharge application. Biosci. J. 2020, 36, 1461-1470. [CrossRef]

119. Guo, X.W.; Cheng, Q.L.; Yu, G.G.; Wang, H.; Tian, Z.L.; Shi, Z.S.; Cui, Z.C.; Zhu, S. The functions of hydrophobic elastic polyurethane combined with an antibacterial triclosan derivative in the dentin restoration interface. J. Mech. Behav. Biomed. Mater. 2020, 102, 9. [CrossRef]

120. Gutierrez, M.F.; Malaquias, P.; Hass, V.; Matos, T.P.; Lourenco, L.; Reis, A.; Loguercio, A.D.; Farago, P.V. The role of copper nanoparticles in an etch-and-rinse adhesive on antimicrobial activity, mechanical properties and the durability of resindentine interfaces. J. Dent. 2017, 61, 12-20. [CrossRef]

121. Gutierrez, M.F.; Malaquias, P.; Matos, P.; Szesz, A.; Souza, S.; Bermudez, J.; Reis, A.; Loguercio, A.D.; Farago, P.V. Mechanical and microbiological properties and drug release modeling of an etch-and-rinse adhesive containing copper nanoparticles. Dent. Mater. 2017, 33, 309-320. [CrossRef]

122. Hafez, A.A.; Cox, C.F.; Tarim, B.; Otsuki, M.; Akimoto, N. An in vivo evaluation of hemorrhage control using sodium hypochlorite and direct capping with a one- or two-component adhesive system in exposed nonhuman primate pulps. Quintessence Int. 2002, 33, 261-272.

123. Hamama, H.H.; Yiu, C.K.; Burrow, M.F. Effect of silver diamine fluoride and potassium iodide on residual bacteria in dentinal tubules. Aust. Dent. J. 2015, 60, 80-87. [CrossRef]

124. Han, Q.; Li, B.L.; Zhou, X.D.; Ge, Y.; Wang, S.P.; Li, M.Y.; Ren, B.; Wang, H.H.; Zhang, K.K.; Xu, H.H.K.; et al. Anti-Caries Effects of Dental Adhesives Containing Quaternary Ammonium Methacrylates with Different Chain Lengths. Materials 2017, 10, 643. [CrossRef]

125. Hashimoto, M.; Hirose, N.; Kitagawa, H.; Yamaguchi, S.; Imazato, S. Improving the durability of resin-dentin bonds with an antibacterial monomer MDPB. Dent. Mater. J. 2018, 37, 620-627. [CrossRef] [PubMed]

126. Hashimoto, M.; Sasaki, J.I.; Yamaguchi, S.; Kawai, K.; Kawakami, H.; Iwasaki, Y.; Imazato, S. Gold Nanoparticles Inhibit Matrix Metalloproteases without Cytotoxicity. J. Dent. Res. 2015, 94, 1085-1091. [CrossRef] [PubMed]

127. He, J.W.; Soderling, E.; Lassila, L.V.; Vallittu, P.K. Preparation of antibacterial and radio-opaque dental resin with new polymerizable quaternary ammonium monomer. Dent. Mater. 2015, 31, 575-582. [CrossRef] [PubMed]

128. Melo, M.A.S.; Cheng, L.; Weir, M.D.; Hsia, R.C.; Rodrigues, L.K.A.; Xu, H.H.K. Novel dental adhesive containing antibacterial agents and calcium phosphate nanoparticles. J. Biomed. Mater. Res. Part B 2013, 101B, 620-629. [CrossRef] [PubMed]

129. Herrera, M.; Castillo, A.; Bravo, M.; Liebana, J.; Carrion, P. Antibacterial activity of resin adhesives, glass ionomer and resin-modified glass ionomer cements and a compomer in contact with dentin caries samples. Oper. Dent. 2000, 25, 265-269. [PubMed]

130. Hirose, N.; Kitagawa, R.; Kitagawa, H.; Maezono, H.; Mine, A.; Hayashi, M.; Haapasalo, M.; Imazato, S. Development of a Cavity Disinfectant Containing Antibacterial Monomer MDPB. J. Dent. Res. 2016, 95, 1487-1493. [CrossRef]

131. Huang, B.; Cuitizouitch, D.G.; Santerre, J.P.; Finer, Y. Biodegradation of resin-dentin interfaces is dependent on the restorative material, mode of adhesion, esterase or MMP inhibition. Dent. Mater. 2018, 34, 1253-1262. [CrossRef]

132. Huang, L.; Xiao, Y.H.; Xing, X.D.; Li, F.; Ma, S.; Qi, L.L.; Chen, J.H. Antibacterial activity and cytotoxicity of two novel cross-linking antibacterial monomers on oral pathogens. Arch. Oral Biol. 2011, 56, 367-373. [CrossRef] 
133. Huang, L.; Yu, F.; Sun, X.; Dong, Y.; Lin, P.T.; Yu, H.H.; Xiao, Y.H.; Chai, Z.G.; Xing, X.D.; Chen, J.H. Antibacterial activity of a modified unfilled resin containing a novel polymerizable quaternary ammonium salt MAE-HB. Sci. Rep. 2016, 6, 8. [CrossRef]

134. Ibrahim, M.S.; AlQarni, F.D.; Al-Dulaijan, Y.A.; Weir, M.D.; Oates, T.W.; Xu, H.H.K.; Melo, M.A.S. Tuning Nano-Amorphous Calcium Phosphate Content in Novel Rechargeable Antibacterial Dental Sealant. Materials 2018, 11, 1544. [CrossRef]

135. Imazato, S.; Kinomoto, Y.; Tarumi, H.; Ebisu, S.; Tay, F.R. Antibacterial activity and bonding characteristics of an adhesive resin containing antibacterial monomer MDPB. Dent. Mater. 2003, 19, 313-319. [CrossRef]

136. Imazato, S.; Kinomoto, Y.; Tarumi, H.; Torii, M.; Russell, R.R.B.; McCabe, J.F. Incorporation of antibacterial monomer MDPB into dentin primer. J. Dent. Res. 1997, 76, 768-772. [CrossRef] [PubMed]

137. Imazato, S.; Kuramoto, A.; Takahashi, Y.; Ebisu, S.; Peters, M.C. In vitro antibacterial effects of the dentin primer of Clearfil Protect Bond. Dent. Mater. 2006, 22, 527-532. [CrossRef] [PubMed]

138. Imazato, S.; Ma, S.; Chen, J.H.; Xu, H.H.K. Therapeutic polymers for dental adhesives: Loading resins with bio-active components. Dent. Mater. 2014, 30, 97-104. [CrossRef]

139. Imazato, S.; Tay, F.R.; Kaneshiro, A.V.; Takahashi, Y.; Ebisu, S. An in vivo evaluation of bonding ability of comprehensive antibacterial adhesive system incorporating MDPB. Dent. Mater. 2007, 23, 170-176. [CrossRef]

140. Imazato, S.; Walls, A.W.G.; Kuramoto, A.; Ebisu, S. Penetration of an antibacterial dentine-bonding system into demineralized human root dentine in vitro. Eur. J. Oral Sci. 2002, 110, 168-174. [CrossRef]

141. Inagaki, L.T.; Alonso, R.C.B.; Araujo, G.A.S.; De Souza, E.J.C.; Anibal, P.C.; Hofling, J.F.; Pascon, F.M.; Puppin-Rontani, R.M. Effect of monomer blend and chlorhexidine-adding on physical, mechanical and biological properties of experimental infiltrants. Dent. Mater. 2016, 32, E307-E313. [CrossRef]

142. Jaymand, M.; Lotfi, M.; Barar, J.; Kimyai, S. Synthesis and characterization of potential multifunctional methacrylate-based dental monomers. Res. Chem. Intermed. 2017, 43, 5707-5722. [CrossRef]

143. Jiang, M.; Mei, M.L.; Wong, M.C.M.; Chu, C.H.; Lo, E.C.M. Effect of silver diamine fluoride solution application on the bond strength of dentine to adhesives and to glass ionomer cements: A systematic review. BMC Oral Health 2020, 20, 10. [CrossRef]

144. Jo,J.K.; El-Fiqi, A.; Lee, J.H.; Kim, D.A.; Kim, H.W.; Lee, H.H. Rechargeable microbial anti-adhesive polymethyl methacrylate incorporating silver sulfadiazine-loaded mesoporous silica nanocarriers. Dent. Mater. 2017, 33, E361-E372. [CrossRef]

145. Jung, J.H.; Kim, D.H.; Yoo, K.H.; Yoon, S.Y.; Kim, Y.; Bae, M.K.; Chung, J.; Ko, C.C.; Kwon, Y.H.; Kim, Y.I. Dentin sealing and antibacterial effects of silver-doped bioactive glass/mesoporous silica nanocomposite: An in vitro study. Clin. Oral Investig. 2019, 23, 253-266. [CrossRef] [PubMed]

146. Kapdan, A.; Oztas, N. Effects of chlorhexidine and gaseous ozone on microleakage and on the bond strength of dentin bonding agents with compomer restoration on primary teeth. J. Dent. Sci. 2015, 10, 46-54. [CrossRef]

147. Kim, C.S.; Ozer, F.; Mante, F.K. Fracture mechanics of dental adhesives supplemented with Polymethylvinyl-ether-co-maleic anhydride. J. Adhes. Sci. Technol. 2017, 31, 1116-1124. [CrossRef]

148. Kim, H.J.; Kwon, T.Y.; Kim, K.H.; Kwon, S.T.; Cho, D.H.; Son, J.S. Long-term release of chlorhexidine from dental adhesive resin system using human serum albumin nanoparticles. Polym. Bull. 2014, 71, 875-886. [CrossRef]

149. Kitagawa, R.; Kitagawa, H.; Izutani, N.; Hirose, N.; Hayashi, M.; Imazato, S. Development of an Antibacterial Root Canal Filling System Containing MDPB. J. Dent. Res. 2014, 93, 1277-1282. [CrossRef]

150. Koizumi, H.; Hamama, H.H.; Burrow, M.F. Effect of a silver diamine fluoride and potassium iodide-based desensitizing and cavity cleaning agent on bond strength to dentine. Int. J. Adhes. Adhes. 2016, 68, 54-61. [CrossRef]

151. Konar, M.; Nayak, N.; Priyadarsini, S.; Mishra, M.; Sahoo, H. Antimicrobial activity of nanoparticle-based dental fillers on novel chromogenic bacteria Enterobacter ludwigii. Mater. Res. Express 2019, 6, 10. [CrossRef]

152. Koulaouzidou, E.A.; Helvatjoglu-Antoniades, M.; Palaghias, G.; Karanika-Kouma, A.; Antoniades, D. Cytotoxicity evaluation of an antibacterial dentin adhesive system on established cell lines. J. Biomed. Mater. Res. Part B 2008, 84B, 271-276. [CrossRef]

153. Kramer, N.; Mohwald, M.; Lucker, S.; Domann, E.; Zorzin, J.I.; Rosentritt, M.; Frankenberger, R. Effect of microparticulate silver addition in dental adhesives on secondary caries in vitro. Clin. Oral Investig. 2015, 19, 1673-1681. [CrossRef] 
154. Kuang, X.Y.; Chen, V.; Xu, X. Novel Approaches to the Control of Oral Microbial Biofilms. Biomed. Res. Int. 2018, 2018, 13. [CrossRef]

155. Kwon, T.Y.; Hong, S.H.; Kim, Y.K.; Kim, K.H. Antibacterial Effects of 4-META/MMA-TBB Resin Containing Chlorhexidine. J. Biomed. Mater. Res. Part B 2010, 92B, 561-567. [CrossRef] [PubMed]

156. Lapinska, B.; Konieczka, M.; Zarzycka, B.; Sokolowski, K.; Grzegorczyk, J.; Lukomska-Szymanska, M. Flow Cytometry Analysis of Antibacterial Effects of Universal Dentin Bonding Agents on Streptococcus mutans. Molecules 2019, 24, 532. [CrossRef] [PubMed]

157. Lee, S.J.; Heo, M.; Lee, D.; Han, S.; Moon, J.H.; Lim, H.N.; Kwon, I.K. Preparation and characterization of antibacterial orthodontic resin containing silver nanoparticles. Appl. Surf. Sci. 2018, 432, 317-323. [CrossRef]

158. Lessa, F.C.R.; Nogueira, I.; Huck, C.; Hebling, J.; Costa, C.A.D. Transdentinal Cytotoxic Effects of Different Concentrations of Chlorhexidine Gel Applied on Acid-Conditioned Dentin Substrate. J. Biomed. Mater. Res. Part B 2010, 92B, 40-47. [CrossRef]

159. Li, F.; Chai, Z.G.; Sun, M.N.; Wang, F.; Ma, S.; Zhang, L.; Fang, M.; Chen, J.H. Anti-biofilm Effect of Dental Adhesive with Cationic Monomer. J. Dent. Res. 2009, 88, 372-376. [CrossRef] [PubMed]

160. Li, F.; Chen, J.H.; Chai, Z.G.; Zhang, L.; Xiao, Y.H.; Fang, M.; Ma, S. Effects of a dental adhesive incorporating antibacterial monomer on the growth, adherence and membrane integrity of Streptococcus mutans. J. Dent. 2009, 37, 289-296. [CrossRef] [PubMed]

161. Li, F.; Majd, H.; Weir, M.D.; Arola, D.D.; Xu, H.H.K. Inhibition of matrix metalloproteinase activity in human dentin via novel antibacterial monomer. Dent. Mater. 2015, 31, 284-292. [CrossRef] [PubMed]

162. Li, F.; Weir, M.D.; Fouad, A.F.; Xu, H.H.K. Effect of salivary pellicle on antibacterial activity of novel antibacterial dental adhesives using a dental plaque microcosm biofilm model. Dent. Mater. 2014, 30, 182-191. [CrossRef]

163. Li, F.; Weir, M.D.; Chen, J.H.; Xu, H.H.K. Comparison of quaternary ammonium-containing with nano-silvercontaining adhesive in antibacterial properties and cytotoxicity. Dent. Mater. 2013, 29, 450-461. [CrossRef]

164. Li, F.; Weir, M.D.; Chen, J.H.; Xu, H.H.K. Effect of charge density of bonding agent containing a new quaternary ammonium methacrylate on antibacterial and bonding properties. Dent. Mater. 2014, 30, 433-441. [CrossRef]

165. Li, F.; Weir, M.D.; Fouad, A.F.; Xu, H.H.K. Time-kill behaviour against eight bacterial species and cytotoxicity of antibacterial monomers. J. Dent. 2013, 41, 881-891. [CrossRef] [PubMed]

166. Li, F.; Weir, M.D.; Xu, H.H.K. Effects of Quaternary Ammonium Chain Length on Antibacterial Bonding Agents. J. Dent. Res. 2013, 92, 932-938. [CrossRef] [PubMed]

167. Li, S.; Yu, X.L.; Liu, F.; Deng, F.L.; He, J.W. Synthesis of antibacterial dimethacrylate derived from niacin and its application in preparing antibacterial dental resin system. J. Mech. Behav. Biomed. Mater. 2020, 102, 7. [CrossRef] [PubMed]

168. Li, W.; Qi, M.L.; Sun, X.L.; Chi, M.H.; Wan, Y.; Zheng, X.F.; Li, C.Y.; Wang, L.; Dong, B. Novel dental adhesive containing silver exchanged EMT zeolites against cariogenic biofilms to combat dental caries. Microporous Mesoporous Mater. 2020, 299, 10. [CrossRef]

169. Li, Y.C.; Hu, X.Y.; Ruan, J.P.; Arola, D.D.; Ji, C.; Weir, M.D.; Oates, T.W.; Chang, X.F.; Zhang, K.; Xu, H.H.K. Bonding durability, antibacterial activity and biofilm $\mathrm{pH}$ of novel adhesive containing antibacterial monomer and nanoparticles of amorphous calcium phosphate. J. Dent. 2019, 81, 91-101. [CrossRef] [PubMed]

170. Li, Y.C.; Hu, X.Y.; Xia, Y.; Ji, Y.D.; Ruan, J.P.; Weir, M.D.; Lin, X.Y.; Nie, Z.H.; Gu, N.; Masri, R.; et al. Novel magnetic nanoparticle-containing adhesive with greater dentin bond strength and antibacterial and remineralizing capabilities. Dent. Mater. 2018, 34, 1310-1322. [CrossRef]

171. Liang, J.G.; Li, M.Y.; Ren, B.A.; Wu, T.M.; Xu, H.H.K.; Liu, Y.; Peng, X.; Yang, G.; Weir, M.D.; Zhang, S.Y.; et al. The anti-caries effects of dental adhesive resin influenced by the position of functional groups in quaternary ammonium monomers. Dent. Mater. 2018, 34, 400-411. [CrossRef]

172. Liang, K.N.; Wang, S.P.; Tao, S.Y.; Xiao, S.M.; Zhou, H.; Wang, P.; Cheng, L.; Zhou, X.D.; Weir, M.D.; Oates, T.W.; et al. Dental remineralization via poly(amido amine) and restorative materials containing calcium phosphate nanoparticles. Int. J. Oral Sci. 2019, 11, 12. [CrossRef]

173. Liang, X.X.; Huang, Q.T.; Liu, F.; He, J.W.; Lin, Z.M. Synthesis of novel antibacterial monomers (UDMQA) and their potential application in dental resin. J. Appl. Polym. Sci. 2013, 129, 3373-3381. [CrossRef]

174. Liu, D.; Peng, X.; Wang, S.P.; Han, Q.; Li, B.L.; Zhou, X.X.; Ren, B.; Xu, H.H.K.; Weir, M.D.; Li, M.Y.; et al. A novel antibacterial resin-based root canal sealer modified by Dimethylaminododecyl Methacrylate. Sci. Rep. 2019, 9, 9. [CrossRef] 
175. Liu, Y.; Zhang, L.; Niu, L.N.; Yu, T.; Xu, H.H.K.; Weir, M.D.; Oates, T.W.; Tay, F.R.; Chen, J.H. Antibacterial and remineralizing orthodontic adhesive containing quaternary ammonium resin monomer and amorphous calcium phosphate nanoparticles. J. Dent. 2018, 72, 53-63. [CrossRef] [PubMed]

176. Lobo, M.M.; Goncalves, R.B.; Pimenta, L.A.F.; Bedran-Russo, A.K.B.; Pereira, P.N.R. In vitro evaluation of caries inhibition promoted by self-etching adhesive systems containing antibacterial agents. J. Biomed. Mater. Res. Part B 2005, 75B, 122-127. [CrossRef] [PubMed]

177. Luo, W.X.; Huang, Q.T.; Liu, F.; Lin, Z.M.; He, J.W. Synthesis of antibacterial methacrylate monomer derived from thiazole and its application in dental resin. J. Mech. Behav. Biomed. Mater. 2015, 49, 61-68. [CrossRef] [PubMed]

178. Ma, S.; Shan, L.Q.; Xiao, Y.H.; Li, F.; Huang, L.; Shen, L.J.; Chen, J.H. The cytotoxicity of methacryloxylethyl cetyl ammonium chloride, a cationic antibacterial monomer, is related to oxidative stress and the intrinsic mitochondrial apoptotic pathway. Braz. J. Med. Biol. Res. 2011, 44, 1125-1133. [CrossRef] [PubMed]

179. Machado, A.H.S.; Garcia, I.M.; Da Motta, A.D.; Leitune, V.C.B.; Collares, F.M. Triclosan-loaded chitosan as antibacterial agent for adhesive resin. J. Dent. 2019, 83, 33-39. [CrossRef]

180. Magro, M.G.; Kuga, M.C.; Victorino, K.R.; Vazquez-Garcia, F.A.; Aranda-Garcia, A.J.; Faria, N.B.; Faria, G.; Shinohara, A.L. Evaluation of the Interaction Between Sodium Hypochlorite and Several Formulations Containing Chlorhexidine and its Effect on the Radicular Dentin-SEM and Push-Out Bond Strength Analysis. Microsc. Res. Tech. 2014, 77, 17-22. [CrossRef]

181. Maia, A.C.; Mangabeira, A.; Vieira, R.; Neves, A.D.; Lopes, R.T.; Pires, T.M.; Viana, G.M.; Cabral, L.M.; Cavalcante, L.M.; Portela, M.B. Experimental composites containing quaternary ammonium methacrylates reduce demineralization at enamel-restoration margins after cariogenic challenge. Dent. Mater. 2019, 35, E175-E183. [CrossRef]

182. Manouchehri, F.; Sadeghi, B.; Najafi, F.; Mosslemin, M.H.; Niakan, M. Synthesis and characterization of novel polymerizable bis-quaternary ammonium dimethacrylate monomers with antibacterial activity as an efficient adhesive system for dental restoration. Polym. Bull. 2019, 76, 1295-1315. [CrossRef]

183. Markham, M.D.; Tsujimoto, A.; Barkmeier, W.W.; Jurado, C.A.; Fischer, N.G.; Watanabe, H.; Baruth, A.G.; Latta, M.A.; Garcia-Godoy, F. Influence of 38\% silver diamine fluoride application on bond stability to enamel and dentin using universal adhesives in self-etch mode. Eur. J. Oral Sci. 2020. [CrossRef]

184. Martim, G.C.; Kupfer, V.L.; Moises, M.P.; Dos Santos, A.; Buzzetti, P.H.M.; Rinaldi, A.W.; Rubira, A.F.; Girotto, E.M. Physical-chemical properties of dental composites and adhesives containing silane-modified SBA-15. J. Mech. Behav. Biomed. Mater. 2018, 80, 277-284. [CrossRef]

185. Matsuo, K.; Yoshihara, K.; Nagaoka, N.; Makita, Y.; Obika, H.; Okihara, T.; Matsukawa, A.; Yoshida, Y.; Van Meerbeek, B. Rechargeable anti-microbial adhesive formulation containing cetylpyridinium chloride montmorillonite. Acta Biomater. 2019, 100, 388-397. [CrossRef] [PubMed]

186. Meiers, J.C.; Miller, G.A. Antibacterial activity of dentin bonding systems, resin modified glass ionomers, and polyacid modified composite resins. Oper. Dent. 1996, 21, 257-264. [PubMed]

187. Melinte, V.; Buruiana, T.; Aldea, H.; Matiut, S.; Silion, M.; Buruiana, E.C. Photopolymerizable phosphate acrylates as comonomers in dental adhesives with or without triclosan monomer units. Mater. Sci. Eng. C-Mater. Biol. Appl. 2014, 34, 176-185. [CrossRef] [PubMed]

188. Melinte, V.; Buruiana, T.; Chibac, A.; Mares, M.; Aldea, H.; Buruiana, E.C. New acid BisGMA analogs for dental adhesive applications with antimicrobial activity. Dent. Mater. 2016, 32, E314-E326. [CrossRef] [PubMed]

189. Melo, M.A.S.; Cheng, L.; Zhang, K.; Weir, M.D.; Rodrigues, L.K.A.; Xu, H.H.K. Novel dental adhesives containing nanoparticles of silver and amorphous calcium phosphate. Dent. Mater. 2013, 29, 199-210. [CrossRef] [PubMed]

190. Melo, M.A.S.; Weir, M.D.; Passos, V.F.; Rolim, J.P.M.; Lynch, C.D.; Rodrigues, L.K.A.; Xu, H.H.K. Human In Situ Study of the effect of Bis(2-Methacryloyloxyethyl) Dimethylammonium Bromide Immobilized in Dental Composite on Controlling Mature Cariogenic Biofilm. Int. J. Mol. Sci. 2018, 19, 3443. [CrossRef] [PubMed]

191. Mestres, G.; Abdolhosseini, M.; Bowles, W.; Huang, S.H.; Aparicio, C.; Gorr, S.U.; Ginebra, M.P. Antimicrobial properties and dentin bonding strength of magnesium phosphate cements. Acta Biomater. 2013, 9, 8384-8393. [CrossRef]

192. Mestres, G.; Ginebra, M.P. Novel magnesium phosphate cements with high early strength and antibacterial properties. Acta Biomater. 2011, 7, 1853-1861. [CrossRef]

193. Minick, G.T.; Oesterle, L.J.; Newman, S.M.; Shellhart, W.C. Bracket bond strengths of new adhesive systems. Am. J. Orthod. Dentofac. Orthop. 2009, 135, 771-776. [CrossRef] 
194. Mocquot, C.; Cabrera, A.; Colon, P.; Bosco, J.; Grosgogeat, B.; Pradelle-Plasse, N. Effect of a hyperbaric environment (diving conditions) on adhesive restorations: An in vitro study. Br. Dent. J. 2017, 223, 347-351. [CrossRef]

195. Monjaras-Avila, A.J.; Zavala-Alonso, N.V.; Martinez-Castanon, G.A.; Patino-Marin, N.; Flores, D.S.H.; Ruiz, F. Sodium Hypochlorite as Fluorotic Dentin Pretreatment of Two-Step Self-Etch Adhesive with Silver Nanoparticle: Atomic Force Microscope and Adhesive Microtensile Bond Strength Evaluation. J. Nanomater. 2017, 2017, 1381929. [CrossRef]

196. Moreira, D.M.; Oei, J.; Rawls, H.R.; Wagner, J.; Chu, L.R.; Li, Y.M.; Zhang, W.; Whang, K. A novel antimicrobial orthodontic band cement with in situ-generated silver nanoparticles. Angle Orthod. 2015, 85, 175-183. [CrossRef] [PubMed]

197. Muratovska, I.; Kitagawa, H.; Hirose, N.; Kitagawa, R.; Imazato, S. Antibacterial activity and dentin bonding ability of combined use of Clearfil SE Protect and sodium hypochlorite. Dent. Mater. J. 2018, 37, 460-464. [CrossRef] [PubMed]

198. Nishida, M.; Imazato, S.; Takahashi, Y.; Ebisu, S.; Ishimoto, T.; Nakano, T.; Yasuda, Y.; Saito, T. The influence of the antibacterial monomer 12-methacryloyloxydodecylpyridinium bromide on the proliferation, differentiation and mineralization of odontoblast-like cells. Biomaterials 2010, 31, 1518-1532. [CrossRef] [PubMed]

199. Ohmori, K.; Maeda, N.; Kohno, A. Evaluation of antibacterial activity of three dentin primers using an in vitro tooth model. Oper. Dent. 1999, 24, 279-285.

200. Okeke, U.C.; Snyder, C.R.; Frukhtbeyn, S.A. Synthesis, Purification and Characterization of Polymerizable Multifunctional Quaternary Ammonium Compounds. Molecules 2019, 24, 1464. [CrossRef]

201. Ozel, E.; Kolayli, F.; Tuna, E.B.; Er, D. In vitro antibacterial activity of various adhesive materials against oral streptococci. Biotechnol. Biotechnol. Equip. 2016, 30, 121-126. [CrossRef]

202. Ozer, F.; Karakaya, S.; Unlu, N.; Erganis, O.; Kav, K.; Imazato, S. Comparison of antibacterial activity of two dentin bonding systems using agar well technique and tooth cavity model. J. Dent. 2003, 31, 111-116. [CrossRef]

203. Palasuk, J.; Windsor, L.J.; Platt, J.A.; Lvov, Y.; Geraldeli, S.; Bottino, M.C. Doxycycline-loaded nanotube-modified adhesives inhibit MMP in a dose-dependent fashion. Clin. Oral Investig. 2018, 22, 1243-1252. [CrossRef]

204. Pan, Y.H.; Wang, J.; Yang, Y.Q.; Nie, R.R.; Meng, X.F. Study on Preparation of Antibacterial Dental Resin Materials. J. Biomater. Tissue Eng. 2018, 8, 1580-1587. [CrossRef]

205. Pedrosa, V.O.; Florio, F.M.; Turssi, C.P.; Amaral, F.L.B.; Basting, R.T.; Franca, F.M.G. Influence of pH Cycling on the Microtensile Bond Strength of Self-etching Adhesives Containing MDPB and Fluoride to Dentin and Microhardness of Enamel and Dentin Adjacent to Restorations. J. Adhes. Dent. 2012, 14, 525-534. [CrossRef] [PubMed]

206. Peralta, S.L.; Carvalho, P.H.A.; Van de Sande, F.H.; Pereira, C.M.P.; Piva, E.; Lund, R.G. Self-etching dental adhesive containing a natural essential oil: Anti-biofouling performance and mechanical properties. Biofouling 2013, 29, 345-355. [CrossRef] [PubMed]

207. Peralta, S.L.; De Carvalho, P.H.A.; Ccahuana-Vasquez, R.A.; De Pereira, C.M.P.; Cury, J.A.; Piva, E.; Lund, R.G. Cytotoxicity, genotoxicity and antibiofilm activity on Streptococcus mutans of an experimental self-etching adhesive system containing natural Butia capitata oil. Int. J. Adhes. Adhes. 2017, 78, 95-101. [CrossRef]

208. Pinheiro, S.L.; Soares, H.H.; Ribeiro, M.C. Microbial contamination and inhibitory effect against Streptococcus mutans from fifth-generation bonding systems. J. Appl. Biomater. Biomech. 2010, 8, 52-55. [PubMed]

209. Pinto, C.F.; Berger, S.B.; Cavalli, V.; Da Cruz, S.E.B.; Goncalves, R.B.; Ambrosano, G.M.B.; Giannini, M. In situ antimicrobial activity and inhibition of secondary caries of self-etching adhesives containing an antibacterial agent and/or fluoride. Am. J. Dent. 2015, 28, 167-173. [PubMed]

210. Pinto, C.F.; Leme, A.F.P.; Ambrosano, G.M.B.; Giannini, M. Effect of a Fluoride- and Bromide-containing Adhesive System on Enamel Around Composite Restorations Under High Cariogenic Challenge In Situ. J. Adhes. Dent. 2009, 11, 293-297.

211. Poggio, C.; Arciola, C.R.; Cepurnykh, S.; Chiesa, M.; Scribante, A.; Selan, L.; Imbriani, M.; Visai, L. In vitro antibacterial activity of different self-etch adhesives. Int. J. Artif. Organs 2012, 35, 847-853. [CrossRef]

212. Polydorou, O.; Pelz, K.; Hahn, P. Antibacterial effect of an ozone device and its comparison with two dentin-bonding systems. Eur. J. Oral Sci. 2006, 114, 349-353. [CrossRef] 
213. Polydorou, O.; Rogatti, P.; Bolek, R.; Wolkewitz, M.; Kummerer, K.; Hellwig, E. Elution of monomers from three different bonding systems and their antibacterial effect. Odontology 2013, 101, 170-176. [CrossRef]

214. Porenczuk, A.; Grzeczkowicz, A.; Maciejewska, I.; Golas, M.; Piskorska, K.; Kolenda, A.; Gozdowski, D.; Kopec-Swoboda, E.; Granicka, L.; Olczak-Kowalczyk, D. An initial evaluation of cytotoxicity, genotoxicity and antibacterial effectiveness of a disinfection liquid containing silver nanoparticles alone and combined with a glass-ionomer cement and dentin bonding systems. Adv. Clin. Exp. Med. 2019, 28, 75-83. [CrossRef]

215. Priyadarshini, B.M.; Mitali, K.; Lu, T.B.; Handral, H.K.; Dubey, N.; Fawzy, A.S. PLGA nanoparticles as chlorhexidine-delivery carrier to resin-dentin adhesive interface. Dent. Mater. 2017, 33, 830-846. [CrossRef] [PubMed]

216. Pupo, Y.M.; Farago, P.V.; Nadal, J.M.; Esmerino, L.A.; Maluf, D.F.; Zawadzki, S.F.; Michel, M.D.; Dos Santos, F.A.; Gomes, O.M.M.; Gomes, J.C. An innovative quaternary ammonium methacrylate polymer can provide improved antimicrobial properties for a dental adhesive system. J. Biomater. Sci. Polym. Ed. 2013, 24, 1443-1458. [CrossRef] [PubMed]

217. Pupo, Y.M.; Farago, P.V.; Nadal, J.M.; Kovalik, A.C.; Dos Santos, F.A.; Gomes, O.M.M.; Gomes, J.C. Effect on vascular permeability of a self-etching adhesive system containing an antimicrobial quaternary ammonium polymer QAMP into subcutaneous tissue of rats. Arch. Oral Biol. 2015, 60, 1138-1145. [CrossRef] [PubMed]

218. Pupo, Y.M.; Farago, P.V.; Nadal, J.M.; Simao, L.C.; Esmerino, L.A.; Gomes, O.M.M.; Gomes, J.C. Effect of a Novel Quaternary Ammonium Methacrylate Polymer (QAMP) on Adhesion and Antibacterial Properties of Dental Adhesives. Int. J. Mol. Sci. 2014, 15, 8998-9015. [CrossRef]

219. Pupo, Y.M.; Nadal, J.M.; Maluf, D.F.; De Lara, E.L.; Saito, R.E.; Michel, M.D.; Antunes, S.R.M.; Toledo, M.D.; Gomes, J.C.; Farago, P.V. Effect of hydroxyapatite morphology and quaternary ammonium polymer co-inclusion on bond strength, cytotoxicity, and cell morphology of self-etching adhesive. Int. J. Adhes. Adhes. 2019, 92, 7-15. [CrossRef]

220. Ren, L.Y.; Pan, Y.H.; Liang, Q.; He, S.W.; Liu, Y.; Fan, Y.; Meng, X.F.; Chen, M. In Situ Synthesis of Dental Resin Matrix Containing Silver Nanoparticles. J. Nanosci. Nanotechnol. 2019, 19, 5774-5782. [CrossRef]

221. Rezaeian, Z.; Beigi-Boroujeni, S.; Atai, M.; Ebrahimibagha, M.; Ozcan, M. A novel thymol-doped enamel bonding system: Physico-mechanical properties, bonding strength, and biological activity. J. Mech. Behav. Biomed. Mater. 2019, 100, 8. [CrossRef]

222. Rolland, S.L.; McCabe, J.F.; Robinson, C.; Walls, A.W.G. In vitro biofilm formation on the surface of resin-based dentine adhesives. Eur. J. Oral Sci. 2006, 114, 243-249. [CrossRef]

223. Rusu, L.C.; Ardelean, L.C.; Jitariu, A.A.; Miu, C.A.; Streian, C.G. An Insight into the Structural Diversity and Clinical Applicability of Polyurethanes in Biomedicine. Polymers 2020, 12, 1197. [CrossRef]

224. Sabatini, C.; Mennito, A.S.; Wolf, B.J.; Pashley, D.H.; Renne, W.G. Incorporation of bactericidal poly-acrylic acid modified copper iodide particles into adhesive resins. J. Dent. 2015, 43, 546-555. [CrossRef]

225. Schmalz, G.; Ergucu, Z.; Hiller, K.A. Effect of dentin on the antibacterial activity of dentin bonding agents. J. Endod. 2004, 30, 352-358. [CrossRef] [PubMed]

226. Schmidlin, P.R.; Zehnder, M.; Gohring, T.N.; Waltimo, T.M. Glutaraldehyde in bonding systems disinfects dentin in vitro. J. Adhes. Dent. 2004, 6, 61-64. [PubMed]

227. Sharma, S.; Lavender, S.; Woo, J.; Guo, L.H.; Shi, W.Y.; Kilpatrick-Liverman, L.; Gimzewski, J.K. Nanoscale characterization of effect of L-arginine on Streptococcus mutans biofilm adhesion by atomic force microscopy. Microbiology 2014, 160, 1466-1473. [CrossRef] [PubMed]

228. Silva, P.A.M.; Garcia, I.M.; Nunes, J.; Visioli, F.; Leitune, V.C.B.; Melo, M.A.; Collares, F.M. Myristyltrimethylammonium Bromide (MYTAB) as a Cationic Surface Agent to Inhibit Streptococcus mutans Grown over Dental Resins: An In Vitro Study. J. Func. Biomater. 2020, 11, 9. [CrossRef] [PubMed]

229. Song, L.Y.; Ge, X.P.; Ye, Q.; Boone, K.; Xie, S.X.; Misra, A.; Tamerler, C.; Spencer, P. Modulating pH through lysine integrated dental adhesives. Dent. Mater. 2018, 34, 1652-1660. [CrossRef]

230. Song, L.Y.; Ye, Q.; Ge, X.P.; Misra, A.; Tamerler, C.; Spencer, P. New silyl-functionalized BisGMA provides autonomous strengthening without leaching for dental adhesives. Acta Biomater. 2019, 83, 130-139. [CrossRef]

231. Spencer, P.; Ye, Q.; Song, L.Y.; Parthasarathy, R.; Boone, K.; Misra, A.; Tamerler, C. Threats to adhesive/dentin interfacial integrity and next generation bio-enabled multifunctional adhesives. J. Biomed. Mater. Res. Part $B$ 2019, 107, 2673-2683. [CrossRef] 
232. Stape, T.H.S.; Tjaderhane, L.; Tezvergil-Mutluay, A.; Yanikian, C.R.F.; Szesz, A.L.; Loguercio, A.D.; Martins, L.R.M. Dentin bond optimization using the dimethyl sulfoxide-wet bonding strategy: A 2-year in vitro study. Dent. Mater. 2016, 32, 1472-1481. [CrossRef]

233. Stenhagen, I.S.R.; Rukke, H.V.; Dragland, I.S.; Kopperud, H.M. Effect of methacrylated chitosan incorporated in experimental composite and adhesive on mechanical properties and biofilm formation. Eur. J. Oral Sci. 2019, 127, 81-88. [CrossRef]

234. Stewart, C.A.; Hong, J.H.; Hatton, B.D.; Finer, Y. Responsive antimicrobial dental adhesive based on drug-silica co-assembled particles. Acta Biomater. 2018, 76, 283-294. [CrossRef]

235. Su, M.X.; Yao, S.Y.; Gu, L.S.; Huang, Z.H.; Mai, S. Antibacterial effect and bond strength of a modified dental adhesive containing the peptide nisin. Peptides 2018, 99, 189-194. [CrossRef] [PubMed]

236. Sun, J.; Petersen, E.J.; Watson, S.S.; Sims, C.M.; Kassman, A.; Frukhtbeyn, S.; Skrtic, D.; Ok, M.T.; Jacobs, D.S.; Reipa, V.; et al. Biophysical characterization of functionalized titania nanoparticles and their application in dental adhesives. Acta Biomater. 2017, 53, 585-597. [CrossRef] [PubMed]

237. Sun, J.R.; Watson, S.S.; Allsopp, D.A.; Stanley, D.; Skrtic, D. Tuning photo-catalytic activities of $\mathrm{TiO}_{2}$ nanoparticles using dimethacrylate resins. Dent. Mater. 2016, 32, 363-372. [CrossRef] [PubMed]

238. Suo, L.; Li, Z.J.; Luo, F.; Chen, J.Y.; Jia, L.L.; Wang, T.; Pei, X.B.; Wan, Q.B. Effect of dentin surface modification using carbon nanotubes on dental bonding and antibacterial ability. Dent. Mater. J. 2018, 37, 229-236. [CrossRef] [PubMed]

239. Thomas, R.; Snigdha, S.; Bhavitha, K.B.; Babu, S.; Ajith, A.; Radhakrishnan, E.K. Biofabricated silver nanoparticles incorporated polymethyl methacrylate as a dental adhesive material with antibacterial and antibiofilm activity against Streptococcus mutans. 3 Biotech 2018, 8, 10. [CrossRef]

240. Thome, T.; Mayer, M.P.A.; Imazato, S.; Geraido-Martins, V.R.; Marques, M.M. In vitro analysis of inhibitory effects of the antibacterial monomer MDPB-containing restorations on the progression of secondary root caries. J. Dent. 2009, 37, 705-711. [CrossRef]

241. Tiwari, S.K.; Wang, S.P.; Huang, Y.N.; Zhou, X.D.; Xu, H.H.K.; Ren, B.A.; Peng, X.; Weir, M.D.; Li, M.Y.; Cheng, L. The Antibacterial Effects of Quaternary Ammonium Salts in the Simulated Presence of Inhibitors in Root Canals: A Preliminary In-Vitro Study. Coatings 2020, 10, 181. [CrossRef]

242. Tonini, R.; Giovarruscio, M.; Gorni, F.; Ionescu, A.; Brambilla, E.; Mikhailovna, I.M.; Luzi, A.; Pires, P.M.; Sauro, S. In Vitro Evaluation of Antibacterial Properties and Smear Layer Removal/Sealer Penetration of a Novel Silver-Citrate Root Canal Irrigant. Materials 2020, 13, 194. [CrossRef]

243. Torres-Mendez, F.; Martinez-Castanon, G.A.; Torres-Gallegos, I.; Zavala-Alonso, N.V.; Patino-Marin, N.; Nino-Martinez, N.; Ruiz, F. Effects of silver nanoparticles on the bonding of three adhesive systems to fluorotic enamel. Dent. Mater. J. 2017, 36, 266-274. [CrossRef]

244. Umer, D.; Yiu, C.K.Y.; Burrow, M.F.; Niu, L.N.; Tay, F.R. Effect of a novel quaternary ammonium silane on dentin protease activities. J. Dent. 2017, 58, 19-27. [CrossRef]

245. Walter, R.; Duarte, W.R.; Pereira, P.N.R.; Heymann, H.O.; Swift, E.J.; Arnold, R.R. In vitro inhibition of bacterial growth using different dental adhesive systems. Oper. Dent. 2007, 32, 388-393. [CrossRef] [PubMed]

246. Wang, S.P.; Wang, H.H.; Ren, B.A.; Li, X.D.; Wang, L.; Zhou, H.; Weir, M.D.; Zhou, X.D.; Masri, R.M.; Oates, T.W.; et al. Drug resistance of oral bacteria to new antibacterial dental monomer dimethylaminohexadecyl methacrylate. Sci. Rep. 2018, 8, 11. [CrossRef] [PubMed]

247. Wang, S.P.; Zhang, K.K.; Zhou, X.D.; Xu, N.; Xu, H.H.K.; Weir, M.D.; Ge, Y.; Wang, S.D.; Li, M.Y.; Li, Y.Q.; et al. Antibacterial Effect of Dental Adhesive Containing Dimethylaminododecyl Methacrylate on the Development of Streptococcus mutans Biofilm. Int. J. Mol. Sci. 2014, 15, 12791-12806. [CrossRef]

248. Wang, S.P.; Zhou, C.C.; Ren, B.; Li, X.D.; Weir, M.D.; Masri, R.M.; Oates, T.W.; Cheng, L.; Xu, H.K.H. Formation of persisters in Streptococcus mutans biofilms induced by antibacterial dental monomer. J. Mater. Sci. Mater. Med. 2017, 28, 10. [CrossRef] [PubMed]

249. Wang, X.Y.; Wang, B.H.; Wang, Y.H. Antibacterial orthodontic cement to combat biofilm and white spot lesions. Am. J. Orthod. Dentofac. Orthop. 2015, 148, 974-981. [CrossRef]

250. Welch, K.; Cai, Y.L.; Engqvist, H.; Stromme, M. Dental adhesives with bioactive and on-demand bactericidal properties. Dent. Mater. 2010, 26, 491-499. [CrossRef]

251. Wu, T.M.; Li, B.L.; Zhou, X.D.; Hu, Y.; Zhang, H.J.; Huang, Y.K.; Xu, H.H.K.; Guo, Q.; Li, M.Y.; Feng, M.Y.; et al. Evaluation of Novel Anticaries Adhesive in a Secondary Caries Animal Model. Caries Res. 2018, 52, $14-21$. [CrossRef] 
252. Xiao, Y.H.; Ma, S.; Chen, J.H.; Chai, Z.G.; Li, F.; Wang, Y.J. Antibacterial Activity and Bonding Ability of an Adhesive Incorporating an Antibacterial Monomer DMAE-CB. J. Biomed. Mater. Res. Part B 2009, 90B, 813-817. [CrossRef]

253. Xie, S.X.; Boone, K.; VanOosten, S.K.; Yuca, E.; Song, L.Y.; Ge, X.P.; Ye, Q.; Spencer, P.; Tamerler, C. Peptide Mediated Antimicrobial Dental Adhesive System. Appl. Sci. 2019, 9, 557. [CrossRef]

254. Xie, X.J.; Wang, L.; Xing, D.; Arola, D.D.; Weir, M.D.; Bai, Y.X.; Xu, H.H.K. Protein-repellent and antibacterial functions of a calcium phosphate rechargeable nanocomposite. J. Dent. 2016, 52, 15-22. [CrossRef]

255. Xie, X.J.; Wang, L.; Xing, D.; Zhang, K.; Weir, M.D.; Liu, H.B.; Bai, Y.X.; Xu, H.H.K. Novel dental adhesive with triple benefits of calcium phosphate recharge, protein-repellent and antibacterial functions. Dent. Mater. 2017, 33, 553-563. [CrossRef] [PubMed]

256. Xiong, J.; Shen, L.P.; Jiang, Q.S.; Kishen, A. Effect of Crosslinked Chitosan Nanoparticles on the Bonding Quality of Fiber Posts in Root Canals. J. Adhes. Dent. 2020, 22, 321-330. [CrossRef] [PubMed]

257. Xu, J.J.; Li, X.J.; Zhu, W.P.; Duan, Z.H.; Mao, Y.J.; Li, X.D. Development of Novel Polymerizable Antibacterial Monomer and Its Antibacterial Effects on Dental Adhesive. Chem. J. Chin. Univ. Chin. 2019, 40, 2028-2032. [CrossRef]

258. Yang, H.Y.; Li, K.; Yan, H.Y.; Liu, S.Y.; Wang, Y.K.; Huang, C. High-performance therapeutic quercetin-doped adhesive for adhesive-dentin interfaces. Sci. Rep. 2017, 7, 11. [CrossRef] [PubMed]

259. Yang, S.Y.; Liu, Y.; Mao, J.; Wu, Y.B.; Deng, Y.L.; Qi, S.C.; Zhou, Y.C.; Gong, S.Q. The antibiofilm and collagen-stabilizing effects of proanthocyanidin as an auxiliary endodontic irrigant. Int. Endod. J. 2020, 53, 824-833. [CrossRef] [PubMed]

260. Yi, L.Y.; Yu, J.; Han, L.; Li, T.T.; Yang, H.Y.; Huang, C. Combination of baicalein and ethanol-wet-bonding improves dentin bonding durability. J. Dent. 2019, 90, 10. [CrossRef] [PubMed]

261. Yu, F.; Dong, Y.; Yu, H.H.; Lin, P.T.; Zhang, L.; Sun, X.; Liu, Y.; Xia, Y.N.; Huang, L.; Chen, J.H. Antibacterial Activity and Bonding Ability of an Orthodontic Adhesive Containing the Antibacterial Monomer 2-Methacryloxylethyl Hexadecyl Methyl Ammonium Bromide. Sci. Rep. 2017, 7, 9. [CrossRef]

262. Yu, H.H.; Zhang, L.; Yu, F.; Li, F.; Liu, Z.Y.; Chen, J.H. Epigallocatechin-3-gallate and Epigallocatechin-3-O-(3-O-methyl)-gallate Enhance the Bonding Stability of an Etch-and-Rinse Adhesive to Dentin. Materials 2017, 10, 183. [CrossRef]

263. Yue, S.C.; Wu, J.L.; Zhang, Q.; Zhang, K.; Weir, M.D.; Imazato, S.; Bai, Y.X.; Xu, H.H.K. Novel dental adhesive resin with crack self-healing, antimicrobial and remineralization properties. J. Dent. 2018, 75, 48-57. [CrossRef]

264. Zhang, K.; Cheng, L.; Imazato, S.; Antonucci, J.M.; Lin, N.J.; Lin-Gibson, S.; Bai, Y.X.; Xu, H.H.K. Effects of dual antibacterial agents MDPB and nano-silver in primer on microcosm biofilm, cytotoxicity and dentine bond properties. J. Dent. 2013, 41, 464-474. [CrossRef]

265. Zhang, K.; Cheng, L.; Wu, E.J.; Weir, M.D.; Bai, Y.X.; Xu, H.H.K. Effect of water-ageing on dentine bond strength and anti-biofilm activity of bonding agent containing new monomer dimethylaminododecyl methacrylate. J. Dent. 2013, 41, 504-513. [CrossRef] [PubMed]

266. Zhang, K.; Li, F.; Imazato, S.; Cheng, L.; Liu, H.B.; Arola, D.D.; Bai, Y.X.; Xu, H.H.K. Dual antibacterial agents of nano-silver and 12-methacryloyloxydodecylpyridinium bromide in dental adhesive to inhibit caries. J. Biomed. Mater. Res. Part B 2013, 101B, 929-938. [CrossRef] [PubMed]

267. Zhang, K.; Melo, M.A.S.; Cheng, L.; Weir, M.D.; Bai, Y.; Xu, H.H.K. Effect of quaternary ammonium and silver nanoparticle-containing adhesives on dentin bond strength and dental plaque microcosm biofilms. Dent. Mater. 2012, 28, 842-852. [CrossRef] [PubMed]

268. Zhang, K.; Wang, S.; Zhou, X.; Xu, H.H.K.; Weir, M.D.; Ge, Y.; Li, M.; Wang, S.; Li, Y.; Xu, X.; et al. Effect of Antibacterial Dental Adhesive on Multispecies Biofilms Formation. J. Dent. Res. 2015, 94, 622-629. [CrossRef] [PubMed]

269. Zhang, N.; Chen, C.; Weir, M.D.; Bai, Y.X.; Xu, H.H.K. Antibacterial and protein-repellent orthodontic cement to combat biofilms and white spot lesions. J. Dent. 2015, 43, 1529-1538. [CrossRef]

270. Zhang, N.; Melo, M.A.S.; Bai, Y.X.; Xu, H.H.K. Novel protein-repellent dental adhesive containing 2-methacryloyloxyethyl phosphorylcholine. J. Dent. 2014, 42, 1284-1291. [CrossRef]

271. Zhang, N.; Weir, M.D.; Romberg, E.; Bai, Y.X.; Xu, H.H.K. Development of novel dental adhesive with double benefits of protein-repellent and antibacterial capabilities. Dent. Mater. 2015, 31, 845-854. [CrossRef] 
272. Zhang, N.; Zhang, K.; Weir, M.D.; Xu, D.J.; Reynolds, M.A.; Bai, Y.X.; Xu, H.H.K. Effects of water-aging for 6 months on the durability of a novel antimicrobial and protein-repellent dental bonding agent. Int. J. Oral Sci. 2018, 10, 1-8. [CrossRef]

273. Zhang, W.; Luo, X.J.; Niu, L.N.; Liu, S.Y.; Zhu, W.C.; Epasinghe, J.; Chen, L.; Li, G.H.; Huang, C.; Mao, J.; et al. One-pot synthesis of antibacterial monomers with dual biocidal modes. J. Dent. 2014, 42, 1078-1095. [CrossRef]

274. Zhao, M.D.; Qu, Y.; Liu, J.; Mai, S.; Gu, L.S. A universal adhesive incorporating antimicrobial peptide nisin: Effects on Streptococcus mutans and saliva-derived multispecies biofilms. Odontology 2020, 108, 376-385. [CrossRef]

275. Zhao, Z.L.; Lian, Y.Q. Synthesis of New Antibacterial Acrylic Monomer and Its Application in Dental Restoration Resin-based. Chem. J. Chin. Univ. Chin. 2013, 34, 708-713. [CrossRef]

276. Zhou, H.; Li, F.; Weir, M.D.; Xu, H.H.K. Dental plaque microcosm response to bonding agents containing quaternary ammonium methacrylates with different chain lengths and charge densities. J. Dent. 2013, 41, 1122-1131. [CrossRef] [PubMed]

277. Zhou, H.; Liu, H.B.; Weir, M.D.; Reynolds, M.A.; Zhang, K.; Xu, H.H.K. Three-dimensional biofilm properties on dental bonding agent with varying quaternary ammonium charge densities. J. Dent. 2016, 53, 73-81. [CrossRef] [PubMed]

278. Zhou, H.; Weir, M.D.; Antonucci, J.M.; Schumacher, G.E.; Zhou, X.D.; Xu, H.H.K. Evaluation of three-dimensional biofilms on antibacterial bonding agents containing novel quaternary ammonium methacrylates. Int. J. Oral Sci. 2014, 6, 77-86. [CrossRef]

279. Clarivate Analytics. InCites Indicators Handbook; Clarivate Analytics: Philadelphia, PA, USA, 2018.

280. Available online: https://support.clarivate.com/ScientificandAcademicResearch/s/article/Web-of-ScienceCore-Collection-List-of-field-tags-in-output?language=en_US (accessed on 27 November 2020).

281. Gutmann, J.L. The evolution of America's scientific advancements in dentistry in the past 150 years. J. Am. Dent. Assoc. 2009, 140 (Suppl. 1), 8s-15s. [CrossRef]

282. Imazato, S.; Chen, J.-h.; Ma, S.; Izutani, N.; Li, F. Antibacterial resin monomers based on quaternary ammonium and their benefits in restorative dentistry. Jpn. Dent. Sci. Rev. 2012, 48, 115-125. [CrossRef]

283. Imazato, S.; McCabe, J.F. Influence of Incorporation of Antibacterial Monomer on Curing Behavior of a Dental Composite. J. Dent. Res. 1994, 73, 1641-1645. [CrossRef]

284. Moazami, F.; Sahebi, S.; Ahzan, S. Tooth Discoloration Induced by Imidazolium Based Silver Nanoparticles as an Intracanal Irrigant. J. Dent. 2018, 19, 280-286.

285. Okamura, K. Interdisciplinarity revisited: Evidence for research impact and dynamism. Palgrave Commun. 2019, 5, 141. [CrossRef]

Publisher's Note: MDPI stays neutral with regard to jurisdictional claims in published maps and institutional affiliations.

(C) 2020 by the authors. Licensee MDPI, Basel, Switzerland. This article is an open access article distributed under the terms and conditions of the Creative Commons Attribution (CC BY) license (http://creativecommons.org/licenses/by/4.0/). 